ARTICLE

https://doi.org/10.1038/s41467-019-09554-7

\title{
Reduced nitrogenase efficiency dominates response of the globally important nitrogen fixer Trichodesmium to ocean acidification
}

\author{
Ya-Wei Luo (1) ${ }^{1}$, Dalin Shi (1) ${ }^{2}$, Sven A. Kranz ${ }^{3}$, Brian M. Hopkinson ${ }^{4}$, Haizheng Hong ${ }^{2}$, Rong Shen ${ }^{2} \&$ \\ Futing Zhang ${ }^{2}$
}

The response of the prominent marine dinitrogen $\left(\mathrm{N}_{2}\right)$-fixing cyanobacteria Trichodesmium to ocean acidification $(O A)$ is critical to understanding future oceanic biogeochemical cycles. Recent studies have reported conflicting findings on the effect of $\mathrm{OA}$ on growth and $\mathrm{N}_{2}$ fixation of Trichodesmium. Here, we quantitatively analyzed experimental data on how Trichodesmium reallocated intracellular iron and energy among key cellular processes in response to $\mathrm{OA}$, and integrated the findings to construct an optimality-based cellular model. The model results indicate that Trichodesmium growth rate decreases under OA primarily due to reduced nitrogenase efficiency. The downregulation of the carbon dioxide $\left(\mathrm{CO}_{2}\right)$-concentrating mechanism under OA has little impact on Trichodesmium, and the energy demand of anti-stress responses to $O A$ has a moderate negative effect. We predict that if anthropogenic $\mathrm{CO}_{2}$ emissions continue to rise, $\mathrm{OA}$ could reduce global $\mathrm{N}_{2}$ fixation potential of Trichodesmium by $27 \%$ in this century, with the largest decrease in iron-limiting regions.

\footnotetext{
${ }^{1}$ State Key Laboratory of Marine Environmental Science and College of Ocean and Earth Sciences, Xiamen University, 361102 Xiamen, Fujian, China. ${ }^{2}$ State Key Laboratory of Marine Environmental Science and College of the Environment and Ecology, Xiamen University, 361102 Xiamen, Fujian, China.

${ }^{3}$ Department of Earth, Ocean and Atmospheric Science, Florida State University, Tallahassee, FL 32306, USA. ${ }^{4}$ Department of Marine Sciences, University of Georgia, Athens, GA 30602, USA. These authors contributed equally: Ya-Wei Luo, Dalin Shi. Correspondence and requests for materials should be addressed to Y.-W.L. (email: ywluo@xmu.edu.cn) or to D.S. (email: dshi@xmu.edu.cn)
} 
$\mathrm{M}$ arine $\mathrm{N}_{2}$ fixation conducted primarily by cyanobacteria (diazotrophs) accounts for as much as one half of the input of bioavailable nitrogen $(\mathrm{N})$ to the global ocean ${ }^{1}$. It is thus important to understand how $\mathrm{N}_{2}$ fixation will respond to ocean acidification $\left(\mathrm{OA}\right.$, i.e., the increase of $\mathrm{CO}_{2}$ concentration and the concomitant decrease of $\mathrm{pH}$ in the seawater) caused by the dissolution of anthropogenic $\mathrm{CO}_{2}$ in the ocean ${ }^{2}$. Most previous studies have shown that the growth and $\mathrm{N}_{2}$ fixation of marine diazotrophs, particularly the prominent genus Trichodesmium, increased with $\mathrm{OA}^{3}$. In contrast, recent studies have reported no significant or even negative effects of OA on diazotrophs $^{4-7}$.

The growth enhancement of diazotrophs under $\mathrm{OA}$ is often attributed to the downregulation of $\mathrm{CO}_{2}$-concentrating mechanisms (CCM) under high $\mathrm{CO}_{2}$ concentration, which seemingly saves energetic resources for other cellular processes including $\mathrm{N}_{2}$ fixation $^{8-11}$. Hong et al. ${ }^{7}$, however, reported that OA inhibited the growth and $\mathrm{N}_{2}$ fixation of Trichodesmium, because the beneficial effect of high $\mathrm{CO}_{2}$ concentration was overwhelmed by the negative effect of low $\mathrm{pH}$. Their study suggested that Trichodesmium needed to invest additional cellular resources and energy to cope with the stress imposed by low pH (e.g., cytosolic $\mathrm{pH}$ disturbance). Regardless of whether OA effects are positive or negative, these studies all highlighted the importance of energy metabolism in the response of Trichodesmium to OA, even though they lacked a quantitative understanding of the energy budget.

Iron $(\mathrm{Fe})$ plays a vital role in energy metabolism of Trichodesmium and is often a limiting resource for the diazotroph in a large part of the ocean ${ }^{12-14}$. Trichodesmium normally allocates a significant portion of intracellular $\mathrm{Fe}$ to nitrogenase, an Fe-rich enzyme that catalyzes $\mathrm{N}_{2}$ fixation, and the remaining $\mathrm{Fe}$ is used in photosystems and other cellular processes ${ }^{15-18}$. It has been shown that Trichodesmium can reallocate intracellular $\mathrm{Fe}$ among different cellular processes in response to Fe limitation. For example, under $\mathrm{Fe}$ deficiency Trichodesmium can compromise on $\mathrm{N}_{2}$ fixation to conserve Fe for photosynthesis ${ }^{19,20}$. Conversely, Fe can be reallocated from photosystems to nitrogenase in Fe-limited Trichodesmium to compensate for the decreased nitrogenase efficiency under $\mathrm{OA}^{4,7}$. However, it is not fully understood how the reallocation of $\mathrm{Fe}$ and energy are quantitatively linked. There still exists a gap between experimental results and model predictions of $\mathrm{N}_{2}$ fixation in the future acidified ocean.

In this study, using experimentally-measured intracellular Fe in photosystems and nitrogenase together with other parameters obtained from the literature, we quantitatively analyze intracellular Fe and energy allocations in Trichodesmium in response to $\mathrm{OA}$ and examine how they modulate its growth and $\mathrm{N}_{2}$ fixation. The results of these quantitative analyses provide parameterization schemes for an optimality-based Trichodesmium cellular model, in which growth rate is maximized by optimizing allocation of intracellular Fe and energy under varying levels of $\mathrm{OA}$ and intracellular Fe. By using the model to study different physiological processes, we find that the reduced nitrogenase efficiency dominates the response of Trichodesmium to OA. Furthermore, we project that $\mathrm{N}_{2}$ fixation potential by Trichodesmium in the global ocean may be reduced by $27 \%$ by the end of this century if anthropogenic $\mathrm{CO}_{2}$ emissions continue to rise.

\section{Results}

Trichodesmium cellular model framework. We first constructed a framework for the Trichodesmium cellular model in which $\mathrm{N}_{2}$ fixation is the only source of $\mathrm{N}$ for the diazotroph (Fig. 1). The model uses seawater $p \mathrm{CO}_{2}$ and $\mathrm{pH}$, and intracellular $\mathrm{Fe}$ as input variables, and allows variable allocation of intracellular $\mathrm{Fe}$ and energy among different cellular processes. It should be noted that although the model is conventionally named as a cellular model, it actually simulates the daily-average response of a filamentous trichome consisting of multiple cells, despite the fact that $\mathrm{N}_{2}$ fixation and photosynthesis in Trichodesmium have been shown to be segregated spatially in different cells along a trichome and/ or temporally at different time over a diel cycle ${ }^{21,22}$.

In the model framework (Fig. 1), the total intracellular Fe quota (Fe discussed hereafter refers to Fe quota, i.e., the cellular Fe to carbon ratio, unless otherwise specified), $Q_{\mathrm{Fe}}$, consists of $\mathrm{Fe}$ in nitrogenase $\left(Q_{\mathrm{Fe}}^{\mathrm{NF}}\right)$, photosystems $\left(Q_{\mathrm{Fe}}^{\mathrm{PS}}\right)$, maintenance $\left(Q_{\mathrm{Fe}}^{\mathrm{MT}}\right)$ and storage $\left(Q_{\mathrm{Fe}}^{\mathrm{ST}}\right)$, and the energy produced from the photosystems $(E)$ is allocated to CCM $\left(E^{\mathrm{CCM}}\right)$, carbon $(\mathrm{C})$ fixation $\left(E^{\mathrm{CF}}\right), \mathrm{N}_{2}$ fixation $\left(E^{\mathrm{NF}}\right)$, maintenance $\left(E^{\mathrm{MT}}\right)$ and anti-stress against $\mathrm{OA}$ $\left(E^{\text {Ats }}\right)$ (Fig. 1). Here, the term maintenance collectively refers to all the incalculable cellular processes that use energy or Fe (such as the tricarboxylic acid cycle and DNA protection ${ }^{23}$ ). In this model, the amount of Fe allocated to photosystems determines the energy production rate, and the subsequent allocation of energy determines the $\mathrm{C}$ fixation rate. The $\mathrm{N}_{2}$ fixation rate also depends on the energy allocated to this process and the amount of Fe allocated to nitrogenase. Therefore, at a given condition, the model potentially has a solution for optimal allocation of intracellular $\mathrm{Fe}$ and energy for maximal growth, under which the ratio of $\mathrm{C}$ to $\mathrm{N}$ fixation equals the elemental stoichiometry of Trichodesmium cells and no intracellular $\mathrm{Fe}$ and energy are wasted.

To resolve different intracellular Fe pools, $Q^{\mathrm{Fe}}, Q_{\mathrm{Fe}}^{\mathrm{NF}}$, and $Q_{\mathrm{Fe}}^{\mathrm{PS}}$ were determined under different conditions (Table 1) in culture experiments through quantitative measurements of key proteins (see Methods). We then quantitatively estimated $Q_{\mathrm{Fe}}^{\mathrm{MT}}$ and $Q_{\mathrm{Fe}}^{\mathrm{ST}}$ as described below.

Maintenance Fe. We first estimated $Q_{\mathrm{Fe}}^{\mathrm{MT}}$ in the acidified low-Fe treatment by assuming no Fe storage $\left(Q_{\mathrm{Fe}}^{\mathrm{ST}}=0\right)$ under this highly stressful condition (i.e., $Q_{\mathrm{Fe}}^{\mathrm{MT}}=Q_{\mathrm{Fe}}-Q_{\mathrm{Fe}}^{\mathrm{NF}}-Q_{\mathrm{Fe}}^{\mathrm{PS}}$ ) (Table 1). The maintenance Fe use efficiency (IUE) for growth (IUE ${ }^{\mathrm{MT}}$, ratio of carbon-based specific growth rate $g_{\mathrm{c}}$ to $Q_{\mathrm{Fe}}^{\mathrm{MT}}$ ) in this treatment was assumed to be constant and applied to estimate $Q_{\mathrm{Fe}}^{\mathrm{MT}}$ from the growth rates for other treatments (Table 1). It is worth noting that this method could potentially overestimate $Q_{\mathrm{Fe}}^{\mathrm{MT}}$ because first, $Q_{\mathrm{Fe}}^{\mathrm{MT}}$ estimated in the acidified low-Fe treatment in fact was its upper bound; second, less Fe may be needed in maintenance under ambient conditions than acidified conditions ${ }^{7}$; and third, comparing high $\mathrm{Fe}$ to low $\mathrm{Fe}$ conditions, the expression level of Fe-containing proteins involved in maintenance increased relatively less than the increase in growth rate (F. Z., H. H., and D. S., unpublished data). As $Q_{\mathrm{Fe}}^{\mathrm{MT}}$ was nevertheless small (1.2-9.3\% of $Q^{\mathrm{Fe}}$, see Table 1), our results should not be affected significantly. In the model simulation, we also used this estimated $\mathrm{IUE}^{\mathrm{MT}}$ as a constant parameter to calculate $Q_{\mathrm{Fe}}^{\mathrm{MT}}$ under any condition (Eq. 11 in Methods).

Fe storage. With $Q_{\mathrm{Fe}}^{\mathrm{MT}}$ determined, we then can estimate the $\mathrm{Fe}$ storage for all the laboratory treatments: $Q_{\mathrm{Fe}}^{\mathrm{ST}}=Q_{\mathrm{Fe}}-Q_{\mathrm{Fe}}^{\mathrm{NF}}-$ $Q_{\mathrm{Fe}}^{\mathrm{PS}}-Q_{\mathrm{Fe}}^{\mathrm{MT}}$ (Table 1). The Fe storage was quite high in the highFe treatments $\left(>80 \%\right.$ of $Q_{\mathrm{Fe}}$ ), which was consistent with our observation that $Q_{\mathrm{Fe}}$ in Trichodesmium grown at even moderate rates was markedly higher than the Fe in nitrogenase and photosystems in those grown at the highest rates (Table 1). In other words, Trichodesmium put aside large amount of $\mathrm{Fe}$, even if higher growth rates could be achieved by allocating Fe to metabolism. Such a phenomenon is often the result of luxury Fe uptake and is commonly observed in the field. As Fe is often a 


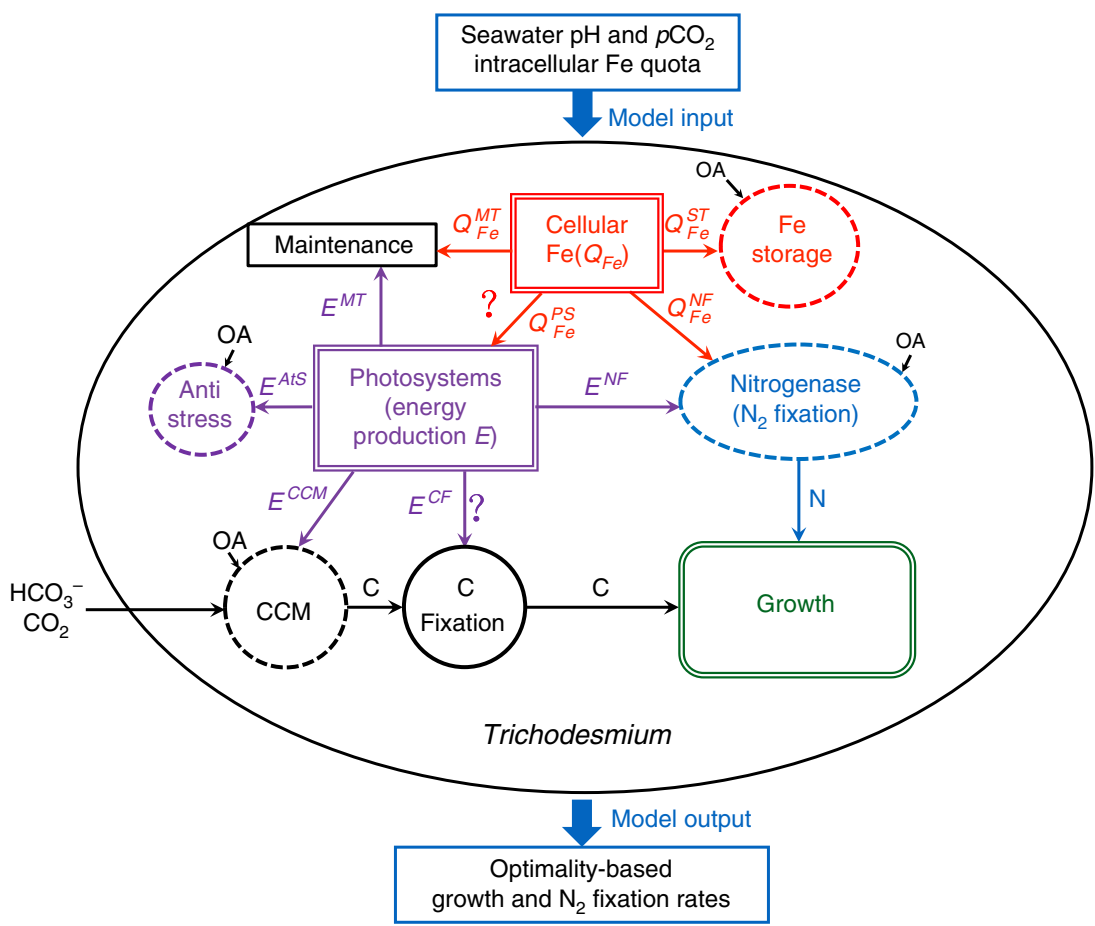

Fig. 1 Trichodesmium cellular model structure. The intracellular Fe (red) and produced energy (purple) are allocated to different cellular processes. The dashed circles and ellipses pointed by OA indicate processes that are influenced by ocean acidification. The two flows with question mark represent unknown parameters to be optimized to maximize Trichodesmium growth

Table 1 Treatments and results of Trichodesmium manipulation experiments

\begin{tabular}{|c|c|c|c|c|c|c|c|c|c|c|c|}
\hline $\begin{array}{l}\mathrm{Fe}_{\mathrm{T}} \\
(\mathrm{nM})\end{array}$ & $\mathrm{Fe}^{\prime}(\mathrm{pM})$ & $\begin{array}{l}\text { Specific } \\
\text { growth rate } \\
\left(d^{-1}\right)\end{array}$ & $\begin{array}{l}N_{2} \text { fixation } \\
{[\mathrm{mol} \mathrm{N}} \\
\left.(\mathrm{mol} \mathrm{C})^{-1} \mathrm{~d}^{-1}\right]\end{array}$ & $\begin{array}{l}\text { POC: } \\
\text { PON }\end{array}$ & $\begin{array}{l}\text { Total } \\
\left(Q_{\mathrm{Fe}}\right)\end{array}$ & $\begin{array}{l}\text { Nitrogen-ase } \\
\left(\mathbf{Q}_{\mathrm{Fe}}^{\mathrm{NF}}\right)\end{array}$ & $\begin{array}{l}\text { Photo-systems } \\
\left(\mathbf{Q}_{\mathrm{Fe}}^{\text {Ps }}\right)\end{array}$ & $\begin{array}{l}\text { Mainten-ance } \\
\left(\mathbf{Q}_{\mathrm{Fe}}^{M \top}\right)\end{array}$ & $\begin{array}{l}\text { Metabolism } \\
\left(\mathbf{Q}_{\mathrm{Fe}}^{*}\right)\end{array}$ & $\begin{array}{l}\text { Storage } \\
\left(\boldsymbol{Q}_{\mathrm{Fe}}^{\mathrm{ST}}\right)\end{array}$ & $\begin{array}{l}\text { Nitrogenase IUE } \\
\text { [mol N (mol Fe) } \\
\left.\mathrm{d}^{-1}\right]\end{array}$ \\
\hline \multicolumn{12}{|c|}{ Ambient $\left(\mathrm{pH}=8.02, \mathrm{pCO}_{\mathbf{2}} \approx 400 \mu \mathrm{atm}\right)$} \\
\hline 10.5 & 32.0 & $0.31 \pm 0.01$ & $0.056 \pm 0.003$ & 5.6 & 27.9 & $16.1 \pm 1.9$ & $6.1 \pm 0.6$ & $(2.6)$ & 24.8 & 3.1 & 3470 \\
\hline 50.5 & 155 & $0.39 \pm 0.01$ & & & 88.6 & & & & & & \\
\hline 150 & 461 & $0.49 \pm 0.01$ & & & 198 & & & & & & \\
\hline 32.5 & 39.5 & $0.22 \pm 0.02$ & $0.032 \pm 0.001$ & 5.9 & 32.5 & $27.0 \pm 5.1$ & $3.7 \pm 0.6$ & 1.86 & 32.5 & 0 & 1200 \\
\hline 125 & 153 & $0.30 \pm 0.01$ & & & 87.8 & & & & & & \\
\hline 380 & 463 & $0.43 \pm 0.04$ & & & 198 & & & & & & \\
\hline 765 & 931 & $0.46 \pm 0.02$ & $0.095 \pm 0.014$ & 5.1 & 331 & $43.6 \pm 3.4$ & $16.7 \pm 0.8$ & (3.9) & 64.3 & 266.7 & 2180 \\
\hline
\end{tabular}

limiting resource in the oceans and its supply is episodic, marine phytoplankton including Trichodesmium take up more Fe than their metabolic requirements and store this excess Fe for later use even under intermediate $\mathrm{Fe}$ limitation. For example, two studies ${ }^{15,24}$ have both reported linear increases in growth rate of Trichodesmium over a range of low $Q_{\mathrm{Fe}}$ values, consistent with a lack of $\mathrm{Fe}$ storage under severe limitation. However, marginal increases in $Q_{\mathrm{Fe}}$ with further increases in inorganic $\mathrm{Fe}\left(\mathrm{Fe}^{\prime}\right)$ (intermediate $\mathrm{Fe}$ limitation) result in lesser increases in growth rate. We interpret these earlier data to suggest that only a small portion of the marginal increase in $Q_{\mathrm{Fe}}$ is used for growth and that perhaps $80 \%$ of this marginal increase is used for storage; this interpretation is consistent with our model results. Although such high $Q_{\mathrm{Fe}}^{\mathrm{ST}}$ is feasible in Trichodesmium given the high Fe storing capacity of $\mathrm{Dps}^{23}$ and ferritin ${ }^{25}$ (260 and $4500 \mathrm{Fe}$ atoms per protein molecule, respectively) (Supplementary Tables 1 and 2,
Supplementary Note 1), it remains unclear why this diazotroph stores such a high amount of Fe particularly under Fe-replete conditions, which warrants further investigation.

We then extrapolated the results from our culture experiments to construct a model scheme for Fe storage quota. Fe storage is expressed as a constant portion $\left(f^{\mathrm{ST}}\right)$ of excess cellular $\mathrm{Fe}$ (the $Q_{\mathrm{Fe}}$ above a threshold $Q_{\mathrm{Fe}}^{\mathrm{c}}$ ), while the residual is defined as metabolic $\mathrm{Fe}\left(Q_{\mathrm{Fe}}^{*}\right.$, sum of $Q_{\mathrm{Fe}}^{\mathrm{NF}}, Q_{\mathrm{Fe}}^{\mathrm{PS}}$, and $\left.Q_{\mathrm{Fe}}^{\mathrm{MT}}\right)$ (Eq. 3 in Methods). We found that $f^{\mathrm{ST}}=90 \%$, while the threshold $Q_{\mathrm{Fe}}^{\mathrm{c}}$ increased under acidified conditions (Fig. 2a). This increase in the threshold $Q_{\mathrm{Fe}}^{c}$ is most likely caused by higher $\mathrm{Fe}$ requirements for metabolic processes under acidified conditions. Thus, we parameterized $Q_{\mathrm{Fe}}^{\mathrm{c}}$ as a function of $\mathrm{pH}$ by further assuming that the relative changes of $Q_{\mathrm{Fe}}^{\mathrm{c}}$ and seawater $\left[\mathrm{H}^{+}\right]$were proportional (Eqs. 2 and 3 in Methods). Although the $\mathrm{pH}$ of seawater medium was used in our calculations, the cellular machinery was located in the cytosol or 
a

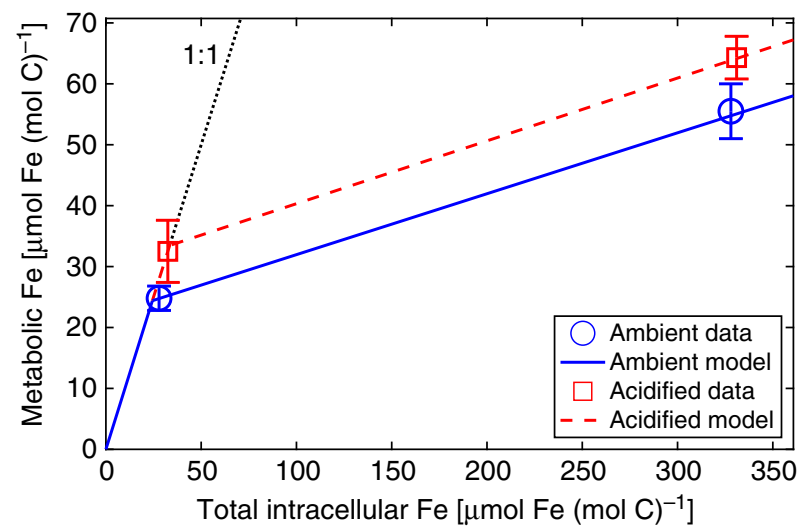

b

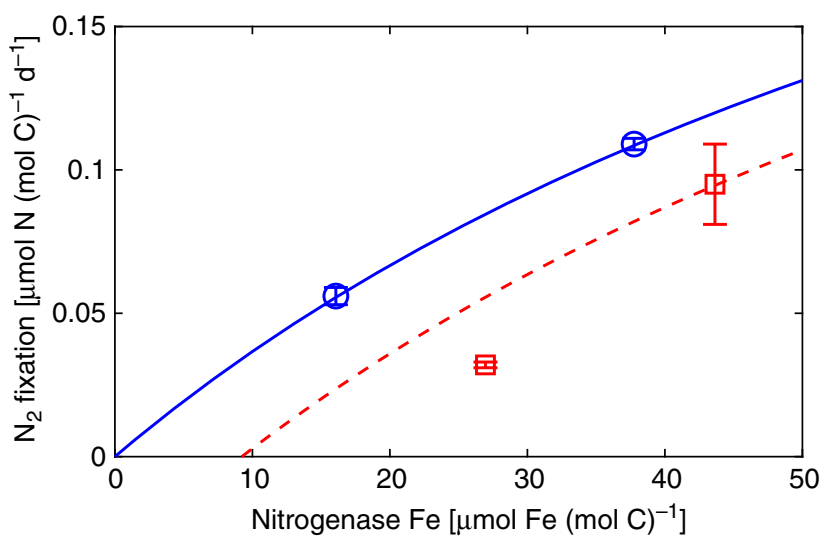

C

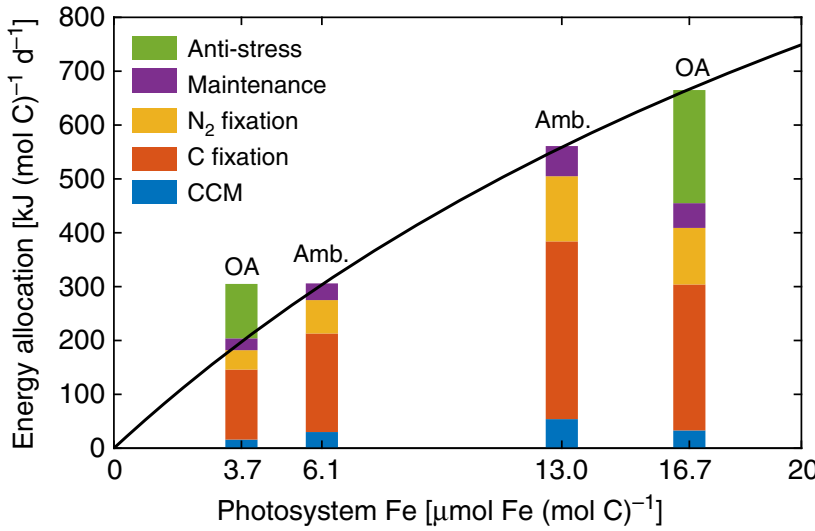

Fig. 2 Illumination of model schemes. a Fe storage model scheme and b nitrogenase $\mathrm{Fe}$-determined $\mathrm{N}_{2}$ fixation rate model scheme compared with the experimental data under ambient (blue) and acidified (red) conditions. c Energy production model scheme (black line) and the estimates (colored bars) of energy allocation to different cellular processes in the culture experiments under ambient (Amb.) and acidified (OA) conditions. For experimental data, error bars represent the s.d. of biological replicates $(n=3)$

the thylakoid membranes of the organism where the $\mathrm{pH}$ was not necessarily the same as in the medium. The extent of $\mathrm{pH}$ decrease and accordingly the relative increase of $\left[\mathrm{H}^{+}\right]$in cytosol were, however, close to those in seawater?

Nitrogenase efficiency and $\mathbf{N}_{\mathbf{2}}$ fixation. Nitrogenase IUE (the ratio of $\mathrm{N}_{2}$ fixation rate to $Q_{\mathrm{Fe}}^{\mathrm{NF}}$ ) under ambient conditions fell in a range that was consistent with the previous estimates for Trichodesmium ${ }^{26}$, and decreased with increasing $Q_{\mathrm{Fe}}^{\mathrm{NF}}$ (Table 1), which may reflect a relationship between $\mathrm{N}_{2}$ fixation rate and gradually saturating nitrogenase concentration. To empirically reproduce this phenomenon, we adopted the Monod equation to parameterize $\mathrm{N}_{2}$ fixation rate as a function of $Q_{\mathrm{Fe}}^{\mathrm{NF}}$ under ambient conditions (Fig. 2a and Eq. 13 in Methods).

The observed nitrogenase IUE was reduced under acidified conditions (Table 1), which may be due to a higher ratio of electron allocation to $\mathrm{H}^{+}$, instead of $\mathrm{N}_{2}$, for $\mathrm{H}_{2}$ evolution ${ }^{4,27}$. The nitrogenase IUE declined more in the low-Fe treatment (65\%) than in the high-Fe treatment (24\%) (Table 1) (discussed later). We hence set up a parameterization scheme to reflect our observations that nitrogenase IUE was inversely proportional to seawater $\left[\mathrm{H}^{+}\right]$, with the reduction inversely proportional to $Q_{\mathrm{Fe}}^{\mathrm{NF}}$ (Fig. 2b and Eq. 14 in Methods).

To match the observed $\mathrm{N}_{2}$ fixation rate of the low-Fe acidified treatment, only a $Q_{\mathrm{Fe}}^{\mathrm{NF}}$ of $\sim 19 \mu \mathrm{mol} \mathrm{Fe}(\mathrm{mol} \mathrm{C})^{-1}$ is required, which is much lower than the observed value of $27.0 \mu \mathrm{mol} \mathrm{Fe}$ $(\text { mol C })^{-1}$ (Fig. 2b). However, the samples for intracellular Fe analyses were collected at mid-day when photosynthesis is downregulated and nitrogenase activity was high ${ }^{21}$. Trichodesmium may significantly reduce photosynthesis to reallocate $\mathrm{Fe}$ to nitrogenase at mid-day ${ }^{4}$, especially in the highly-stressful acidified low-Fe treatment, in compensation for the loss of $\mathrm{N}_{2}$ fixation efficiency at low $\mathrm{pH}$. The extent of the increase in nitrogenase averaged over a diel cycle may not be as large as those appeared in the mid-day samples. This has been observed in a previous study, in which OA caused Trichodesmium grown under low $\mathrm{Fe}$ conditions $(40 \mathrm{pM} \mathrm{Fe}$ ) to increase $\mathrm{NifH}$ (the nitrogenase reductase of the nitrogenase complex) by $47 \%$ at mid-day but by $37 \%$ on average on a daily basis ${ }^{4}$.

CCM energy consumption. To estimate energy consumption rate for the Trichodesmium CCM, we considered a simple scheme including that first, a portion $\left(f^{\mathrm{BC}}\right)$ of total inorganic carbon uptake $(\mathrm{Ci})$ into the cell is from energy-consuming bicarbonate $\left(\mathrm{HCO}_{3}{ }^{-}\right)$transport; second, passive $\mathrm{CO}_{2}$ diffusion contributes the rest of $\mathrm{Ci}$; and third, a portion $\left(l_{\mathrm{k}}\right)$ of $\mathrm{Ci}$ leaks out of the cell as $\mathrm{CO}_{2}$ (Supplementary Figure 1). The $\mathrm{CO}_{2}$ passively diffusing into cytoplasm is converted to $\mathrm{HCO}_{3}{ }^{-}$at the nicotinamide adenine dinucleotide phosphate (NADPH) dehydrogenase complex located at the thylakoid membrane ${ }^{28}$. The mechanistic details of this system have not been determined, but the overall energy cost is thought to be small. NADPH consumption supporting proton removal is likely coupled to ATP generation resulting in a low net energy $\operatorname{cost}^{29}$. We thus neglect this $\mathrm{CO}_{2}$ uptake dependent energy consumption and only consider the energy consumption associated with $\mathrm{HCO}_{3}{ }^{-}$transport. Transport of 1 mol $\mathrm{HCO}_{3}{ }^{-}$costs 1 mol $\operatorname{ATP}^{30}$ (approximately $50 \mathrm{~kJ}^{31}$ ), and building $\mathrm{HCO}_{3}{ }^{-}$ transporters and carboxysomes also requires energy, which, however, is hard to quantify and is assumed to cost additional $20 \%$ energy. Altogether the cost is estimated at $60 \mathrm{~kJ}$ per mol $\mathrm{HCO}_{3}{ }^{-}$transported. Using $f^{\mathrm{BC}}=80 \%$ and $l_{\mathrm{k}}=50 \%$ in Trichodesmium $^{9,32,33}$, $1 \mathrm{~mol} \mathrm{C}$ fixation requires $2.0 \mathrm{~mol} \mathrm{Ci}$, in which $1.6 \mathrm{~mol}$ is from $\mathrm{HCO}_{3}{ }^{-}$transport, and accordingly $96 \mathrm{~kJ}$ of energy (Table 2). It is worth noting that even if building $\mathrm{HCO}_{3}{ }^{-}$ transporters and carboxysomes costs four times more energy (i.e., 100\%), the CCM energy cost rate would increase from 96 to $160 \mathrm{~kJ}(\mathrm{~mol} \mathrm{C})^{-1}$, which is still small compared to the total energy cost (Table 2).

As seawater acidifies, the potential for diffusive $\mathrm{CO}_{2}$ flux increases approximately proportionally with dissolved $\left[\mathrm{CO}_{2}\right]$ in seawater ${ }^{34}$, and accordingly the cellular demand for transport of $\mathrm{HCO}_{3}{ }^{-}$decreases. In addition, the increase of dissolved $\left[\mathrm{CO}_{2}\right]$ in seawater can reduce the cross-membrane $\left[\mathrm{CO}_{2}\right]$ gradient and hence $\mathrm{CO}_{2}$ leakage. However, the reduction of $\mathrm{CO}_{2}$ leakage under 
Table 2 Energy consumption rates of Trichodesmium cellular processes under ambient condition

\begin{tabular}{|c|c|c|c|c|}
\hline & ATP hydrolysis & NADPH oxidation & Energy consumption rate ${ }^{a}$ & References \\
\hline C fixation & 3 per C & 2 per $C$ & $590 \mathrm{~kJ}(\mathrm{~mol} \mathrm{C})^{-1}$ & Raven et al. 60 \\
\hline $\mathrm{CCM}$ & 1.92 per $C^{b}$ & & $96 \mathrm{~kJ}(\mathrm{~mol} \mathrm{C})^{-1}$ & \\
\hline $\mathrm{N}$ fixation include: & $9 \operatorname{per} \mathrm{N}$ & $3 \operatorname{per} N$ & $\begin{array}{l}1,110 \mathrm{~kJ}(\mathrm{~mol} \mathrm{~N})^{-1} \\
=198 \mathrm{~kJ}(\mathrm{~mol} \mathrm{c})^{-1 \mathrm{c}}\end{array}$ & \\
\hline $\mathrm{N}_{2}$ assimilation to $\mathrm{NH}_{4}+$ & $8 \operatorname{per} \mathrm{N}$ & $2 \operatorname{per} \mathrm{N}$ & & Flores and Herrero 61 \\
\hline $\mathrm{NH}_{4}+$ assimilation to glutamate & $1 \operatorname{per} \mathrm{N}$ & $1 \operatorname{per} \mathrm{N}$ & & Flores et al. 62 \\
\hline Maintenance and other processes & & & $100 \mathrm{~kJ}(\mathrm{~mol} \mathrm{C})^{-1}$ & $\sim 10 \%$ of total energy consumption \\
\hline Total & & & $984 \mathrm{~kJ}(\mathrm{~mol} \mathrm{C})^{-1}$ & \\
\hline
\end{tabular}

$\mathrm{OA}$ is fairly small ${ }^{9,33}$, likely because, as in other cyanobacteria, $\mathrm{CO}_{2}$ concentration within Trichodesmium cells is among the highest in phytoplankton ${ }^{35,36}$, and thus the increase of extracellular $\left[\mathrm{CO}_{2}\right]$ should not change the cross-membrane $\left[\mathrm{CO}_{2}\right]$ gradient substantially. We thus parameterized a scheme for the CCM energy consumption (Eq. 6 in Methods), in which a doubling of $p \mathrm{CO}_{2}$ reduced $\mathrm{CO}_{2}$ leakage by $10 \%$, and, together with the reduced $\mathrm{HCO}_{3}{ }^{-}$transport, decreased the CCM energy consumption by $32 \%$. This estimate could depend on the choice of initial $f^{\mathrm{BC}}$ before changing $p \mathrm{CO}_{2}$. For instance, the initial $f^{\mathrm{BC}}$ could be smaller under a lower growth rate as a larger fraction of $\mathrm{Ci}$ can be met by $\mathrm{CO}_{2}$ diffusion. As shown by a model sensitivity test (Supplementary Figure 2), for example, for a doubling of $p \mathrm{CO}_{2}$ the CCM energy consumption can be reduced $\sim 50 \%$ if the initial $f^{\mathrm{BC}}=70 \%$, and can be reduced to zero if the initial $f^{\mathrm{BC}}<50 \%$. Nevertheless, as discussed below, the energy consumed by CCM is small and its saving does not impact model results substantially.

Other energy costs and production under ambient conditions. Energy consumption rates for $\mathrm{C}$ fixation and $\mathrm{N}_{2}$ fixation were estimated based on theoretical energy requirements for ATP hydrolysis and NADPH oxidation of these reactions, and maintenance was assumed to cost $\sim 10 \%$ of total energy (Table 2). From the measured rates of Trichodesmium growth and $\mathrm{N}_{2}$ fixation, we estimated total cellular energy consumption, which equals energy production assuming no energy waste, for the ambient low- and high-Fe treatments (Fig. 2c). Similar to nitrogenase, the IUE of photosystems for energy production decreases with the increase of $Q_{\mathrm{Fe}}^{\mathrm{PS}}$, and we adopted a Monod-like equation to represent the relationship between energy production rate and $\mathrm{Q}_{\mathrm{Fe}}^{\mathrm{PS}}$ (Fig. $2 \mathrm{c}$ and Eq. 4 in Methods).

Anti-stress energy consumption under acidified conditions. If OA does not change the IUE of photosystems, using the parameterization established above (Eq. 4 in Methods), the energy produced in the acidified high-Fe treatment would be $46 \%$ more than the total requirement for the CCM, C and $\mathrm{N}$ fixations, and maintenance (Fig. 2c). We considered this excess energy as the cost for anti-stress against OA, which, for example, is needed for maintaining cytosolic $\mathrm{pH}$ homeostasis ${ }^{7}$. We subsequently scaled the observations and parameterized the anti-stress energy proportional to $\mathrm{C}$-based specific growth rate and relative change of seawater $\left[\mathrm{H}^{+}\right]$(Eq. 7 in Methods).

To simulate the energy production rate in the acidified low-Fe treatment, $6.1 \mu \mathrm{mol} \mathrm{Fe} \mathrm{(mol} \mathrm{C})^{-1}$ is needed by the photosystems (Fig. 2c). This was significantly higher than the measured $3.7 \mu \mathrm{mol} \mathrm{Fe}(\mathrm{mol} \mathrm{C})^{-1}$ (Table 1) (at mid-day), therefore also suggesting that the difference between daily average $\mathrm{Fe}$ in nitrogenase and photosystems can be less than it appeared in the mid-day samples, as discussed above.

Cellular model simulation. The parameterization schemes established above were integrated into the cellular model framework (Fig. 1). As shown by the model equation sequence in Methods, given the input variables of $Q_{\mathrm{Fe}}$ and seawater $p \mathrm{CO}_{2}$ and $\mathrm{pH}$, Trichodesmium growth and $\mathrm{N}_{2}$ fixation rates in the model are a function of only two parameters, i.e., $f_{\mathrm{Fe}}^{\mathrm{PS}}$, the fraction of metabolic $\mathrm{Fe}\left(Q_{\mathrm{Fe}}^{*}\right)$ allocated to photosystems, and $f_{\mathrm{E}}^{\mathrm{CF}}$, the fraction of produced energy allocated to $\mathrm{C}$ fixation, which are solvable by maximizing the growth rate (see Methods).

The simulated growth and $\mathrm{N}_{2}$ fixation rates increase with $Q_{\mathrm{Fe}}$. Above the Fe threshold (at which the cells start to store Fe) the rate of increase is reduced (Fig. 3a, b). The model accurately reproduces most of the measured growth rates under both the ambient and acidified conditions (Fig. 3a). The model also reproduces the $\mathrm{N}_{2}$ fixation rates well, other than a slight overestimation for the acidified low-Fe treatment (Fig. 3b). This likely is because the model uses a constant C:N ratio for biomass, yet the experimentally measured ratio varied (Table 1). The modeled Fe allocation to nitrogenase and photosystems generally reproduces the measurements accurately, except for the acidified low-Fe treatment where the modeled $\mathrm{Fe}$ in photosystems is substantially higher than the measurement values (Fig. $3 \mathrm{c}, \mathrm{d}$ ). This is likely due to the stoichiometric differences in the respective acclimations discussed above.

The simulation results over a range of seawater $\mathrm{pH}$ (and concomitant change in $p \mathrm{CO}_{2}$, See Methods) and $Q_{\mathrm{Fe}}$ show that OA has a large impact on Trichodesmium when $Q_{\mathrm{Fe}}$ is low (Figs 3e, f). When $Q_{\mathrm{Fe}}>50 \mu \mathrm{mol} \mathrm{Fe}(\mathrm{mol} \mathrm{C})^{-1}$, OA changes Trichodesmium growth rate by no more than $\pm 20 \%$ with a $\mathrm{pH}$ change of \pm 0.2 unit (Fig. 3f).

It should be noted that although linear or Monod-like equations are assumed and applied in the cellular model, $\mathrm{N}_{2}$ fixation rates and intracellular Fe allocations which the model is parameterized and tested against are derived experimentally at only two Fe levels (Fig. 2). As the actual underlying relationships are unknown, it is possible that our model results may be off to a certain degree in particular at moderate levels of Fe. Nevertheless, the model reasonably fitted the measured growth rates observed at multiple Fe concentrations (i.e., 5 under ambient conditions and 4 under acidified conditions) (Fig. 3a), indicating that the assumed relationships in our model are reasonably sound. In addition, the $\mathrm{N}_{2}$ fixation rates that the model fitted to were experimentally measured with the acetylene reduction method ${ }^{37}$, using a fixed ratio of $4: 1$ to convert ethylene production to $\mathrm{N}_{2}$ fixation. The ratio however can vary between $3: 1$ and $4: 1^{38}$, and in 

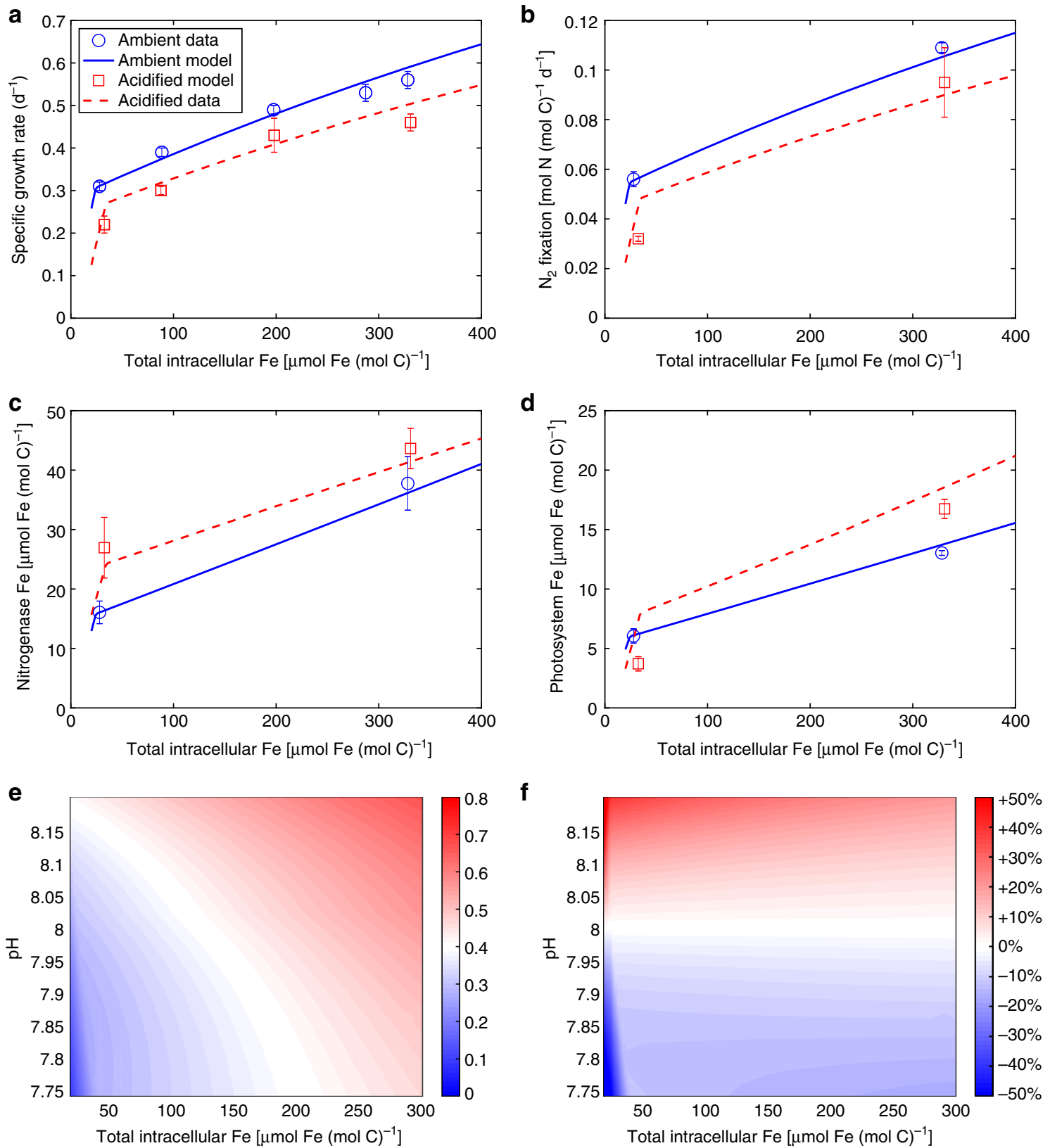

Fig. 3 Cellular model simulation results. a Specific growth rate, $\mathbf{b} \mathrm{N}_{2}$ fixation rate, $\mathbf{c}$ amount of Fe allocated to nitrogenase, and $\mathbf{d}$ amount of Fe allocated to photosystems under ambient (blue), and acidified (red) conditions, compared to the observations. e Growth rate and $\mathbf{f}$ the relative change of growth rate compared to that under $\mathrm{pH} 8.02$ over ranges of seawater $\mathrm{pH}$ and intracellular Fe levels. For experimental data, error bars represent the s.d. of biological replicates $(n=3)$

fact can be lower in Trichodesmium grown under ambient conditions than under acidified conditions ${ }^{4,7}$. Therefore, the actual $\mathrm{N}_{2}$ fixation rates under acidified conditions may be overestimated relative to those under ambient conditions, which would result in an underestimate of the $\mathrm{OA}$ impact on Trichodesmium $\mathrm{N}_{2}$ fixation by up to $33 \%$.

Comparison of different OA effects on Trichodesmium. Model experiments with a decrease of $0.2 \mathrm{pH}$ unit and a concomitant increase in $p \mathrm{CO}_{2}$ (See Methods) show that within a $Q_{\mathrm{Fe}}$ range of 20-300 $\mu \mathrm{mol} \mathrm{Fe} \mathrm{(mol} \mathrm{C)})^{-1}$, CCM downregulation alone increases Trichodesmium growth rate by only $\sim 0.6 \%$, while anti-stress energy consumption and reduced nitrogenase efficiency decrease growth by $\sim 11 \%$ and $18-46 \%$, respectively (Fig. $4 a$ ). The impact of the reduced nitrogenase efficiency diminishes gradually with increasing $Q_{\mathrm{Fe}}$, because, as discussed above, the reduction of nitrogenase efficiency becomes proportionally smaller.

These model experiments reveal that the negative effect of reduced nitrogenase efficiency is more significant than that of the anti-stress energy consumption, because most of the intracellular metabolic Fe of Trichodesmium is in nitrogenase and much less $\mathrm{Fe}$ is in the photosystems (Table 1 and other studies ${ }^{15,16}$ ). The simulated optimal reallocations of the intracellular resources demonstrate that when the anti-stress energy consumption is the only OA effect, a relatively small portion of nitrogenase $\mathrm{Fe}$ $(\sim 15 \%)$ is reallocated to the photosystems, consequently increasing photosystem $\mathrm{Fe}$ greatly by $\sim 40 \%$ (Fig. $4 \mathrm{~b}$ ). As a result, the 

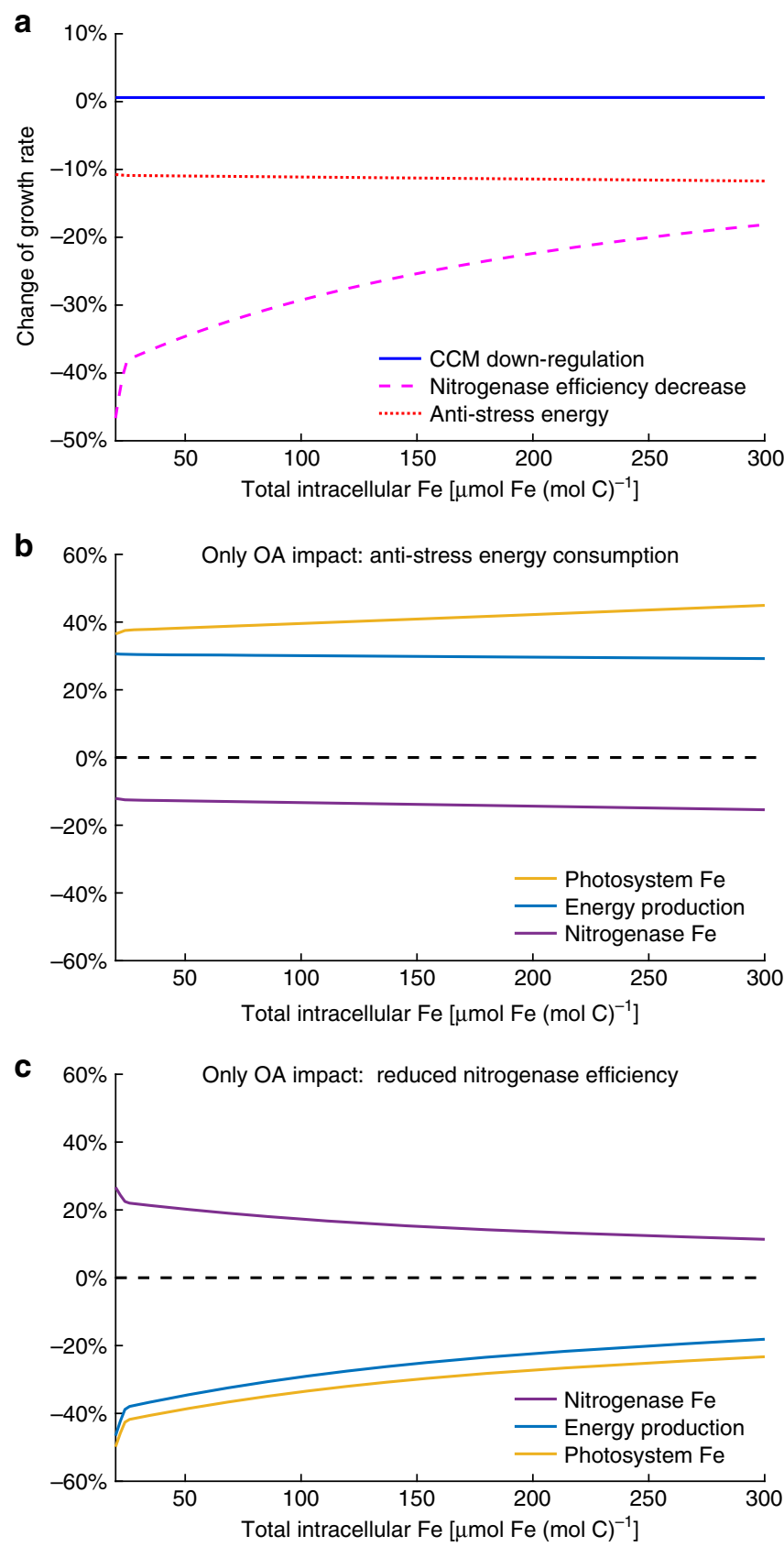

Fig. 4 Comparison of modeled individual impact of ocean acidification (OA) on Trichodesmium. The $\mathrm{pH}$ changes from 8.02 to 7.82 and $\mathrm{pCO}_{2}$ changes accordingly in the simulations. a Relative changes of growth rate when the model enables each of the OA impacts. Also shown the relative changes of nitrogenase $\mathrm{Fe}$, photosystems $\mathrm{Fe}$, and energy production when the model enables $\mathbf{b}$ anti-stress energy or $\mathbf{c}$ the reduced nitrogenase efficiency as the only OA impact

energy production increases by $>30 \%$ (Fig. 4b), which largely compensates for the anti-stress energy requirements, and therefore the decrease of the growth rate is insignificant (Fig. 4a). However, when the reduced nitrogenase efficiency is the only OA effect, reallocation of substantial $\mathrm{Fe}$ from the photosystems (23-50\%) results in a small increase in nitrogenase (11-27\%) (Fig. 4c). This allocation barely compensates for the reduced nitrogenase efficiency, and meanwhile considerably reduces energy production (18-46\%) (Fig. 4c), consequently leading to a greatly reduced growth rate (Fig. $4 a$ ).
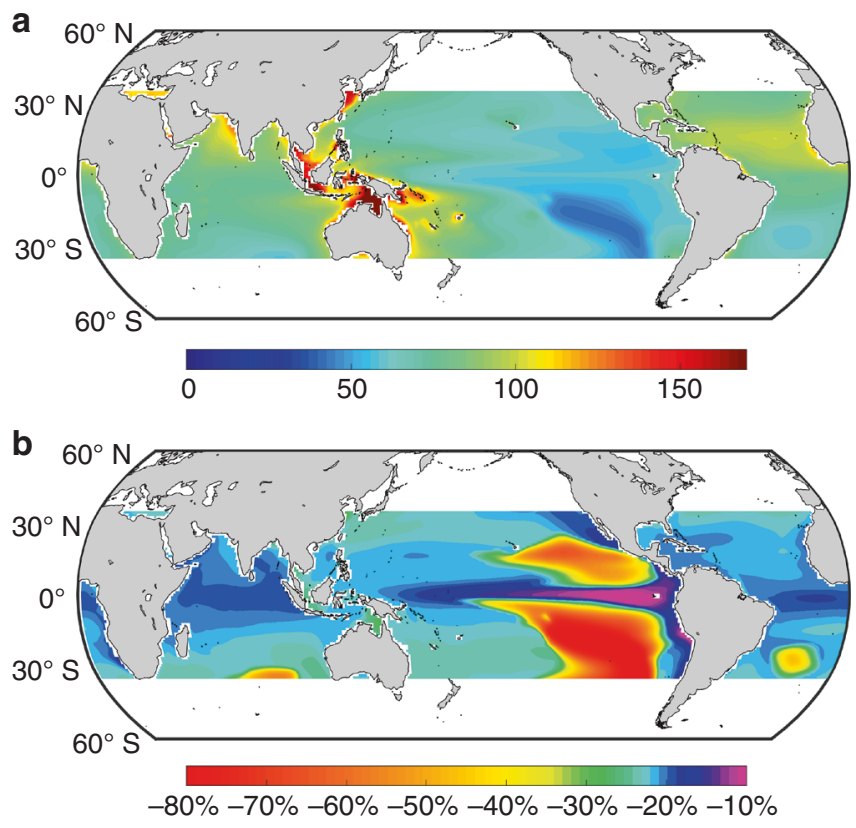

Fig. 5 The projected Trichodesmium $\mathrm{N}_{2}$ fixation potential. a Results [mmol $\mathrm{N}$ ( $\mathrm{mol} \mathrm{C})^{-1} \mathrm{~d}^{-1}$ ] in 1990s and $\mathbf{b}$ relative change from 1990s to 2090s

Projection of global $\mathrm{N}_{2}$ fixation potential by Trichodesmium. The logarithms of in-situ Trichodesmium Fe quota and the modeled surface Fe' (from the Community Earth System ModelBiogeochemistry, CESM-BGC) shows a strong linear relationship $\left(R^{2}=0.65\right)$, with the regression line $\left[\log \left(Q_{\mathrm{Fe}}\right)=-0.17+\right.$ $\left.0.83 \log \left(\mathrm{Fe}^{\prime}\right)\right]$ close to that obtained from a laboratory experiment $^{4}$ (Supplementary Figure 3a). The projected Trichodesmium $Q_{\mathrm{Fe}}$ in the global ocean using this relationship generally matches the experimental observations (Supplementary Figure 3b).

Taking into consideration Fe limitation and $p \mathrm{CO}_{2} / \mathrm{pH}$ only, we estimate Trichodesmium $\mathrm{N}_{2}$ fixation potential in the 1990 s at 76 \pm 20 (mean \pm s.d.) mmol $\mathrm{N}(\mathrm{mol} \mathrm{C})^{-1} \mathrm{~d}^{-1}$, with the highest potential in the oceanic regions near the Indonesian archipelago and north of Australia and the lowest potential in the southeastern and northeastern subtropical Pacific (Fig. 5a). We also project a decrease of Trichodesmium $\mathrm{N}_{2}$ fixation potential from 1990 s to 2090 s by $27 \pm 15 \%$ (mean \pm s.d.) under the Representative Concentration Pathway (RCP) 8.5, a scenario in which anthropogenic greenhouse gas (including $\mathrm{CO}_{2}$ ) emissions continue to rise throughout the 21st century (Fig. 5b). The regions with the largest decrease overlap with those where $\mathrm{Fe}$ is limiting and the $\mathrm{N}_{2}$ fixation potential is low, i.e., the southeastern and northeastern subtropical Pacific. In most of the other oceanic regions, the $\mathrm{N}_{2}$ fixation potential decreases by $\sim 20 \%$.

\section{Discussion}

In the present study, we systematically and quantitatively evaluated the impact of $\mathrm{OA}$ on the prominent marine diazotroph Trichodesmium, by analyzing experimental data and establishing a cellular model that takes into account OA effects on a suite of cellular processes: CCM downregulation, anti-stress energy consumption, reduced nitrogenase efficiency, and increased threshold for Fe luxury uptake. The model was well constrained by the experimental observations, particularly $Q_{\mathrm{Fe}}$ and the nitrogenase and photosystem proteins, and by theoretical estimates of energy consumptions of cellular processes. With these constraints, under given conditions of $\mathrm{OA}$ and $Q_{\mathrm{Fe}}$, the model only depended on two parameters (the fraction of energy allocated to $\mathrm{C}$ fixation, and the fraction of $\mathrm{Fe}$ allocated to photosynthesis), which can be 
determined by optimally allocating intracellular Fe and energy to maximize the growth rate of Trichodesmium. The results demonstrated that Trichodesmium cannot cope with the cumulative stresses imposed by OA and hence may decline in a future, more acidic ocean.

The modeled optimal allocations of intracellular $\mathrm{Fe}$ and energy, and therefore the modeled maximal growth and $\mathrm{N}_{2}$ fixation rates, relied mainly on the values of those parameters explicitly or implicitly related to energy consumption, IUE, and the strength of the OA impacts. The major consumption of cellular energy by $\mathrm{C}$ and $\mathrm{N}_{2}$ fixation was constrained by free energy changes of those biochemical reactions (Table 2). We estimated that the CCM required only $\sim 10 \%$ of total cellular energy (Table 2 and Fig. 2c), which is approximate as inorganic carbon transport processes are not fully understood. For example, CCM costs could be even lower if the $\mathrm{HCO}_{3}{ }^{-}$transport were driven by a gradient of $\mathrm{Na}^{+}$or $\mathrm{H}^{+39}$. We also estimated that a doubling of $\mathrm{pCO}_{2}$ can reduce $\mathrm{CCM}$ energy consumption by $\sim 30 \%$ and therefore change total cellular energy consumption by only $\sim 3 \%$. Additionally, under Fe-limitation, the realized increase in growth rate would be even less than $3 \%$, because the increase in $\mathrm{N}_{2}$ fixation due to the energetic benefit of CCM downregulation would require reallocation of Fe from photosystems to nitrogenase, which in turn would lead to a lower energy production, partially offsetting the benefit of CCM downregulation. Finally, as discussed above, the increase in environmental $\mathrm{CO}_{2}$ may not substantially reduce cellular $\mathrm{CO}_{2}$ leakage in Trichodesmium. Taking into consideration all these factors, our model projections reveal that the benefit of a CCM downregulation for enhanced growth of Trichodesmium is very limited $\left(0.6 \%\right.$ for a doubling of $\left.p \mathrm{CO}_{2}\right)$ (Fig. $\left.4 \mathrm{a}\right)$, which is comparable with an experimental observation that at a given $\mathrm{pH}$ a doubling of $\mathrm{pCO}_{2}$ from 400 to $800 \mu \mathrm{atm}$ led to an increase of Trichodesmium growth rate by only $0.8-3.8 \%{ }^{7}$. In contrast, an OA stimulated increase in Trichodesmium growth and $\mathrm{N}_{2}$ fixation rates of $10-94 \%$ and $35-317 \%$, respectively, as previously reported ${ }^{8-11,40,41}$, would require the CCM energy consumption rate $\sim 4-40$ fold higher than the level estimated in this study, making the CCM cost $36-81 \%$ of total cellular energy. Such a considerable energetic expenditure on the CCM would seem infeasible, given the large, competing energetic demands of other processes (e.g., $\mathrm{C}$ and $\mathrm{N}_{2}$ fixation) in Trichodesmium, even not to mention the energy requirement for coping with the negative impacts of OA. Thus, the positive effect of OA reported previously is likely caused by some of the artificial growth conditions applied that supported overall suboptimal growth rates and potentially altered key physiological processes in Trichodesmium $^{4,7}$.

The anti-stress energy requirement estimated based on the culture experiments was scaled in the model to other conditions, assuming that it was proportional to growth rate and seawater $\left[\mathrm{H}^{+}\right]$, which however remains to be verified. Nevertheless, as discussed above, the model was not very sensitive to the rate of the anti-stress energy consumption as energy can be generated to meet this need by reallocating a small amount of cellular Fe to the photosystems. This, however, assumed that light was not limiting. Our model experiment showed that when cellular energy production is light-limited (see Methods), the anti-stress energy requirement would further reduce Trichodesmium growth rate at high intracellular Fe (Supplementary Figure 4). In our culture experiments, however, Trichodesmium did not appear to be limited by a light intensity of $\sim 80 \mu \mathrm{mol}$ photons $\mathrm{m}^{-2} \mathrm{~s}^{-1}$, which was relatively low compared to that in the surface water of the tropical and subtropical open oceans where Trichodesmium inhabits. Future experiments with Trichodesmium grown under different light and $\mathrm{Fe}$ levels are necessary for a better understanding of the impact of OA on the energy limitations of the diazotroph.

Our model revealed that the response of Trichodesmium to OA was dominated by the reduced nitrogenase efficiency. The model results, particularly the more significant adverse effect of $\mathrm{OA}$ on $\mathrm{N}_{2}$ fixation under Fe limitation, are largely based on an inverse relationship between $Q_{\mathrm{Fe}}$ and the $\mathrm{OA}$-induced reduction of nitrogenase efficiency observed in our culture experiments (Table 1). Although the underlying mechanisms remain unclear, it is possible that under low-Fe conditions OA caused an overall higher degree of stress to cells and thus resulted in a lower level of cellular ATP. Reduced energy supply, in addition to decreased cytosolic $\mathrm{pH}$, may further reduce nitrogenase efficiency by increasing the production of $\mathrm{H}_{2}$ at the expense of $\mathrm{NH}_{3}$, as previously observed in Azotobacter vinelandi ${ }^{27,42}$. In addition, at the contemporary rate of increasing atmospheric $p \mathrm{CO}_{2}$ and accordingly seawater acidification, it is possible that Trichodesmium may evolutionarily adapt to better cope with the decrease in nitrogenase efficiency. The significant luxury uptake and subsequent storage of $\mathrm{Fe}$ by Trichodesmium ( $90 \%$ of cellular $\mathrm{Fe}$ above a threshold in this study), when the Fe supply is high, likely reflect its response to natural fluctuations in Fe availability by storing Fe for later use. On a longer time-scale, it is possible that the diazotroph may evolve to optimally allocate its cellular $\mathrm{Fe}$, investing more in metabolism than in storage to compensate for the reduced nitrogenase efficiency. This phenomenon has already been found in our study where the Fe storage started at a higher threshold of intracellular $\mathrm{Fe}$ (i.e., more $\mathrm{Fe}$ used in metabolic processes) under OA (Fig. 2a), although the full extent to which this can compensate for the negative effects of $\mathrm{OA}$ is unclear. If the compensation becomes increasingly significant in the future, $\mathrm{OA}$ effect on Trichodesmium $\mathrm{N}_{2}$ fixation would be less pronounced than that projected in this study, particularly in areas with high Fe supply. Therefore, the mechanism and the degree of the impact of $\mathrm{OA}$ on nitrogenase efficiency and $\mathrm{Fe}$ storage, possibly in the context of long-term adaptation, seems to be key questions in the future for better predicting the change of marine $\mathrm{N}_{2}$ fixation.

The incorporation of the cellular model we developed into biogeochemical models would help to improve our predictions for $\mathrm{N}_{2}$ fixation and other biogeochemical cycles in the future acidified ocean. Our model used $Q_{\mathrm{Fe}}$ as one of the input variables so that it could be constrained more directly by our experimental data and meanwhile avoided simulating the rather complex and not fully understood Fe chemistry in seawater ${ }^{43}$. A strong correlation between the measured Trichodesmium $\mathrm{Q}_{\mathrm{Fe}}$ and the $\mathrm{Fe}^{\prime}$ predicted by an earth system model (Supplementary Figure 3) allowed the extrapolation from our cellular model to the global ocean (Fig. 5b). It is thus promising that our cellular model can be easily connected with large-scale models.

Caution should be taken when applying the model to diazotrophic species/strains other than the one studied here. It should also be noted that the model only represents intracellular $\mathrm{Fe}$ and energy allocations, and therefore implicitly assumes that other resources, such as phosphorus ${ }^{12}$, temperature ${ }^{44}$, cobalt, and vitamins ${ }^{45}$, do not limit Trichodesmium growth. Growth of Trichodesmium is often limited by the deficiency of phosphorus in surface seawater ${ }^{12}$, which is expected to intensify as a result of augmented water column stratification caused by global warming. Additionally, a recent study shows that the optimal thermal range of Trichodesmium becomes wider under higher $p \mathrm{CO}_{2}$ and thus increasing temperature can help the diazotroph to alleviate the impact of $\mathrm{OA}^{46}$. Therefore, changes in these factors in the future ocean may modulate the OA effect and hence could change our model projections. More manipulative OA experiments on 
Table 3 Model variables and parameters

Symbol Unit

Input variables

$\mathrm{Q}_{\mathrm{Fe}} \quad \quad \mu \mathrm{mol} \mathrm{Fe}(\mathrm{mol} \mathrm{C})^{-1}$

$\mathrm{pH}$

$\mathrm{pCO}_{2} \quad \mu \mathrm{atm}$

Parameters to be optimized

$f_{F e}^{P S}$

Cons

Constant parameters

$\mathrm{pH}_{\text {bsl }}$

$\mathrm{pCO}_{2, b s l} \quad$ Hatm

$Q_{F e, b s l}^{C} \quad \mu \mathrm{mol} \mathrm{Fe}(\mathrm{mol} \mathrm{C})^{-1}$

$\mathrm{OA}^{\mathrm{ST} T}$

fT

$E_{\max }$

$E_{\max }$
$K_{\mathrm{Fe}}^{P S}$
eC CF

$\mathrm{ec}^{\mathrm{CF}}$

$f^{\mathrm{BC}}$

$I_{\mathrm{k}}$

$\mathrm{OA}^{\mathrm{lk}}$

ecCCM

$\mathrm{ec}^{\mathrm{AtS}}$

ec $^{\mathrm{MT}}$

ec NF

IUEMT

$Q_{F e, r e f}^{N F}$

$\mathrm{NF}_{\text {max }}$

$K_{\mathrm{Fe}}^{\mathrm{NF}}$
$r_{\mathrm{N}}^{\mathrm{C}}$

$\mathrm{kJ}(\mathrm{mol} C)^{-1} \mathrm{~d}^{-1}$

$\mu \mathrm{mol} \mathrm{Fe}(\mathrm{mol} \mathrm{C})^{-1}$

$\mathrm{kJ}(\mathrm{mol} \mathrm{C})^{-1}$

$\mathrm{kJ}(\mathrm{mol} \mathrm{C})^{-1}$

$\mathrm{kJ}(\mathrm{mol} \mathrm{C})^{-1}$

$\mathrm{kJ}(\mathrm{mol} \mathrm{C})^{-1}$

$\mathrm{kJ}(\mathrm{mol} \mathrm{N})^{-1}$

$\mathrm{mol} C(\mu \mathrm{mol} \mathrm{Fe})^{-1} d^{-1}$

$\mu \mathrm{mol} \mathrm{Fe}(\mathrm{mol} \mathrm{C})^{-1}$

mol N (mol C $)^{-1} d^{-1}$

$\mu \mathrm{mol} \mathrm{Fe}(\mathrm{mol} \mathrm{C})^{-1}$

$\operatorname{mol~C}(\mathrm{mol} \mathrm{N})^{-1}$
Description

Value

Total intracellular Fe quota

$\mathrm{pH}$ value in medium

Partial pressure of medium dissolved $\mathrm{CO}_{2}$

Fraction of metabolic Fe allocated to photosystems

Fraction of produced energy allocated to $C$ fixation

Medium $\mathrm{pH}$ value under baseline condition

8.02

Medium $\mathrm{pCO}_{2}$ under baseline condition

400

Critical $Q_{\mathrm{Fe}}$ for Fe luxury uptake under baseline condition

24.4

Portion of luxury Fe uptake

Maximum cellular energy production rate

Half-saturating coefficient for energy production

Energy consumption rate of carbon fixation

Contribution of $\mathrm{HCO}_{3}-$ to total inorganic carbon uptake under baseline condition

0.71

$90 \%$

2060

35

590

Percentage of total inorganic carbon uptake leaked as $\mathrm{CO}_{2}$

Coefficient representing relative reduction of $\mathrm{CO}_{2}$ leakage with increasing medium $\mathrm{CO}_{2}$

$80 \%$

$50 \%$

Energy consumption rate of $\mathrm{HCO}_{3}-$ transportation

Coefficient representing energy consumption rate for anti-stress

0.1

60

Energy consumption rate of maintenance

780

Energy consumption rate of $\mathrm{N}_{2}$ fixation

90

Fe use efficiency in maintenance

Reference nitrogenase $\mathrm{Fe}$ used in representing impact of $\mathrm{pH}$ on nitrogenase efficiency

1110

0.12

Maximum $\mathrm{N}_{2}$ fixation rate

Half-saturating coefficient for $\mathrm{N}_{2}$ fixation

Carbon to nitrogen ratio of Trichodesmium cell
0.37

91

5.6
Trichodesmium with these limiting factors are thus needed in order to frame a full picture of the mechanisms and improve accuracy of the projections.

\section{Methods}

Laboratory experimental data. Growth and $\mathrm{N}_{2}$ fixation rates of Trichodesmium at varying $\mathrm{Fe}$ concentrations $\left(\mathrm{Fe}_{\mathrm{T}}\right)$ under ambient $\left(\mathrm{pH}=8.02, p \mathrm{CO}_{2} \approx 400 \mu \mathrm{atm}\right)$ and acidified conditions ( $\left.\mathrm{pH}=7.82, p \mathrm{CO}_{2} \approx 700 \mu \mathrm{atm}\right)$ are obtained from Hong et al. ${ }^{7}$, in which Trichodesmium were pre-acclimated to experimental conditions for 2-3 months before the rates were measured. Inorganic Fe concentration (Fe') (pM) was estimated from $\mathrm{Fe}_{\mathrm{T}}, \mathrm{pH}$, light, temperature, and concentration of the chelating agent EDTA in the medium ${ }^{47}$. The intracellular Fe quota $\left(Q_{\mathrm{Fe}}\right)\left[\mu \mathrm{mol} \mathrm{Fe}(\mathrm{mol} \mathrm{C})^{-1}\right]$ was calculated based on a regression between the logarithms of $\mathrm{Fe}^{\prime}$ and $Q_{\mathrm{Fe}}$ [i.e., $\left.\log \left(Q_{\mathrm{Fe}}\right)=0.734 \log \left(\mathrm{Fe}^{\prime}\right)+0.341\right]^{4}$, which is observed previously with the same organism cultured under the same experimental conditions as in the present study.

Following Shi et al. ${ }^{4}$, cells from each one of the triplicate cultures grown under different conditions (i.e., $\sim 35$ or $\sim 925$ pM Fe' under ambient or acidified conditions) were collected at midday of the photoperiod for quantifying expression of nitrogenase and photosynthetic Fe-containing proteins including: NifH, PsbA, the D1 protein of photosystem II (PSII), PetC, a key subunit of cytochrome (cyt) b6/f complex, and PsaC, the core subunit of photosystem I (PSI), in unit of $\mu \mathrm{mol}$ per $g$ total cellular protein, by immunoblot analyses. Briefly, steady-stately growing cells were collected by filtration onto $3 \mu \mathrm{m}$ polycarbonate membrane filters (Millipore), flash frozen in liquid nitrogen, and then stored at $-80^{\circ} \mathrm{C}$ for later analysis. Proteins were extracted and denatured in an extraction buffer (2\% SDS, $10 \%$ glycerol, and 50 mMTris at $\mathrm{pH} 6.8 ; 1 \% \beta$-mercaptoethanol was added after protein quantification) with heating at $100{ }^{\circ} \mathrm{C}$ for $10 \mathrm{~min}$. Insoluble material was pelleted by centrifugation at $12,000 \mathrm{~g}$ for $10 \mathrm{~min}$, and total protein in the supernatant was quantified using the bicinchoninic acid (BCA) assay (Pierce, Thermo Scientific). Equivalent amounts of total protein $(10 \mu \mathrm{g}$ for $\mathrm{NifH}$ and $\mathrm{PetC}$; $5 \mu \mathrm{g}$ for PsaC; $1 \mu \mathrm{g}$ for PsbA) was separated on a $12 \%$ SDS polyacrylamide gel for $20 \mathrm{~min}$ at $80 \mathrm{~V}$ followed by $60 \mathrm{~min}$ at $120 \mathrm{~V}$ in $1 \times$ SDS running buffer, and then transferred onto a PVDF membrane in ice-cold transfer buffer $(25 \mathrm{mM}$ Tris, $192 \mathrm{mM}$ glycine and $2.5 \%$ methanol) for $20 \mathrm{~min}$ at $300 \mathrm{~mA}$. The membrane was then blocked for $1 \mathrm{~h}$ in TBST buffer (Tris-buffered saline with $0.25 \%$ Tween 20) containing $5 \%$ nonfat milk, followed by $1-2 \mathrm{~h}$ incubation with primary antibody (Agrisera Antibodies, Sweden: NifH, Art no. AS01 021 A; PsbA, Art no. AS05 084 Pet C, Art no. AS08 330; PsaC, Art no. AS10 939) and subsequently three 10-min washes with TBST buffer. The membrane was then probed with alkaline phosphatase-conjugated goat anti-rabbit IgG or anti-chicken IgY for $1 \mathrm{~h}$ or $2 \mathrm{~h}$, respectively, and washed three times again. Following three rinses with PhoA buffer (20 mM Tris, $100 \mathrm{mM} \mathrm{NaCl}$, and $10 \mathrm{mM} \mathrm{MgCl}_{2}, \mathrm{pH} 9.5$ ), protein bands on the membrane were visualized with NBT/BCIP (Roche, Indianapolis, IN, USA) and quantified by densitometry.

Ferredoxin was also estimated by assuming 1:1 ratio to PsaC. The Fe content of the nitrogen complex was estimated as 38 per complex by assuming $2 \mathrm{Fe}$-protein dimers and $1 \mathrm{MoFe}$-protein tetramer per nitrogenase complex, $4 \mathrm{Fe}$ per Fe-protein dimer, and $30 \mathrm{Fe}$ per MoFe-protein tetramer. Further with the ratio of $\mathrm{NifH}$ to nitrogenase complex of $1: 4, \mathrm{Fe}$ in the nitrogenase complex [ $\left.\mu \mathrm{mol} \mathrm{Fe}(\mathrm{g} \text { protein })^{-1}\right]$ was estimated to be $38 / 4 \mathrm{Fe}(\mathrm{NifH})^{-1}$ (Supplementary Table 3). 3, 6, 12, and $2 \mathrm{Fe}$ atoms were assumed for each unit of PSII, cyt b6/f complex, PSI and ferredoxin, respectively $^{4}$, to calculate the $\mathrm{Fe}$ in these proteins $\left[\mu \mathrm{mol} \mathrm{Fe}(\mathrm{g} \text { protein })^{-1}\right]$, and the sum of Fe in these proteins gave an estimate of Fe in photosystems (Supplementary Table 3). Finally, by assuming proteins accounting for $30 \%$ of dry cell mass and $\mathrm{C}$ for $50 \%$ of dry cell mass ${ }^{4}$, a factor of $0.6 \mathrm{~g}$ protein $(\mathrm{g} \mathrm{C})^{-1}$, or $7.2 \mathrm{~g}$ protein $(\mathrm{mol} \mathrm{C})^{-1}$, was applied to convert the estimates to $\mathrm{Fe}$ quota $\left[\mu \mathrm{mol} \mathrm{Fe}(\mathrm{mol} \mathrm{C})^{-1}\right]$ (Supplementary Table 3).

Cellular model equations. Model parameterization schemes based on the quantitative analyses were integrated to a model only depending on two unknown parameters $f_{\mathrm{Fe}}^{\mathrm{PS}}$ (fraction of metabolic Fe allocated to photosystems) and $f_{\mathrm{E}}^{\mathrm{CF}}$ (fraction of produced energy allocated to $\mathrm{C}$ fixation) under given $Q_{\mathrm{Fe}}, \mathrm{pH}$ and $\mathrm{pCO}_{2}$ :

$$
g=G\left(f_{\mathrm{Fe}}^{\mathrm{PS}}, f_{\mathrm{E}}^{\mathrm{CF}}, Q_{\mathrm{Fe}}, \mathrm{pH}, p \mathrm{CO}_{2}\right)
$$

Here we briefly describe the model equations. Description and values of all the model parameters will not be included here but are listed in Table 3.

The threshold of $Q_{\mathrm{Fe}}$ for Fe storage is:

$$
Q_{\mathrm{Fe}}^{\mathrm{c}}=Q_{\mathrm{Fe}, \mathrm{bsl}}^{\mathrm{c}} \cdot\left(1+\mathrm{OA}^{\mathrm{ST}} \cdot d_{\mathrm{r}} H\right)
$$

where $d_{\mathrm{r}} H=10^{-\left(\mathrm{pH}^{-} \mathrm{pH}_{\mathrm{bs}}\right)}-1$ is the relative change of medium $\mathrm{H}^{+}$concentration to a baseline condition $\left(\mathrm{pH}_{\mathrm{bsl}}\right)$. Metabolic $\mathrm{Fe}, \mathrm{Q}_{\mathrm{Fe}}^{*}$, is then calculated from from $Q_{\mathrm{Fe}}^{\mathrm{c}}$ :

$$
Q_{\mathrm{Fe}}^{*}= \begin{cases}Q_{\mathrm{Fe}}, & Q_{\mathrm{Fe}} \leq Q_{\mathrm{Fe}}^{\mathrm{c}} \\ Q_{\mathrm{Fe}}^{\mathrm{c}}+\left(1-f^{\mathrm{ST}}\right) \cdot\left(Q_{\mathrm{Fe}}-Q_{\mathrm{Fe}}^{\mathrm{c}}\right), & Q_{\mathrm{Fe}}>Q_{\mathrm{Fe}}^{\mathrm{c}}\end{cases}
$$


$Q_{\mathrm{Fe}}^{\mathrm{PS}}=f_{\mathrm{Fe}}^{\mathrm{PS}} \cdot Q_{\mathrm{Fe}}^{*}$ is used to determine energy production rate:

$$
E=E_{\max } \cdot \frac{Q_{\mathrm{Fe}}^{\mathrm{PS}}}{K_{\mathrm{Fe}}^{\mathrm{PS}}+Q_{\mathrm{Fe}}^{\mathrm{PS}}}
$$

Therefore, energy allocated to $\mathrm{C}$ fixation, $E^{\mathrm{CF}}=f_{\mathrm{E}}^{\mathrm{CF}} \cdot E$, is used to determined the specific $\mathrm{C}$ fixation rate $\left(g_{\mathrm{C}}\right)$ from the energy consumption rate of carbon fixation:

$$
g_{\mathrm{C}}=E^{\mathrm{CF}} / \mathrm{ec}^{\mathrm{CF}}
$$

Energy consumptions for several processes then can be estimated based on $g_{\mathrm{C}}$. The energy consumption for the CCM is:

$$
E^{\mathrm{CCM}}=\mathrm{ec}^{\mathrm{CCM}} \cdot g_{\mathrm{C}} \cdot \frac{1-\left(1-f^{\mathrm{BC}}\right) \cdot p \mathrm{CO}_{2} / p \mathrm{CO}_{2, \mathrm{bsl}}}{1-l_{\mathrm{k}} \cdot\left[1-\left(p \mathrm{CO}_{2} / p \mathrm{CO}_{2, \mathrm{bsl}}-1\right) \cdot \mathrm{OA}^{\mathrm{lk}}\right]}
$$

The energy consumption for anti-stress is:

$$
E^{\mathrm{AtS}}=\max \left(0, \mathrm{ec}^{\mathrm{AtS}} \cdot g_{\mathrm{C}} \cdot d_{\mathrm{r}} H\right)
$$

The energy consumption for maintenance is:

$$
E^{\mathrm{MT}}=\mathrm{ec}^{\mathrm{MT}} \cdot g_{\mathrm{C}}
$$

Thus, the residual energy is subsequently allocated to $\mathrm{N}_{2}$ fixation:

$$
E^{\mathrm{NF}}=E-E^{\mathrm{CF}}-E^{\mathrm{CCM}}-E^{\mathrm{AtS}}-E^{\mathrm{MT}}
$$

Then we can estimate the energy-limiting $\mathrm{N}_{2}$ fixation rate from energy consumption rate of $\mathrm{N}_{2}$ fixation:

$$
\mathrm{NF}^{\mathrm{E}}=\max \left(0, E^{\mathrm{NF}} / \mathrm{ec}^{\mathrm{NF}}\right)
$$

Maintenance $\mathrm{Fe}$ can also be estimated from $g_{\mathrm{C}}$ :

$$
Q_{\mathrm{Fe}}^{\mathrm{MT}}=g_{\mathrm{C}} / \mathrm{IUE}^{\mathrm{MT}}
$$

Hence the residual $\mathrm{Fe}$ is subsequently allocated to $\mathrm{N}_{2}$ fixation:

$$
Q_{\mathrm{Fe}}^{\mathrm{NF}}=\max \left(0, Q_{\mathrm{Fe}}^{*}-Q_{\mathrm{Fe}}^{\mathrm{PS}}-Q_{\mathrm{Fe}}^{\mathrm{MT}}\right)
$$

and the Fe-limiting $\mathrm{N}_{2}$ fixation rate can be estimated by the following two equations accounting for effect of $Q_{\mathrm{Fe}}^{\mathrm{NF}}$ and $\mathrm{pH}$, respectively:

$$
\begin{gathered}
\mathrm{NF}^{\mathrm{bsl}}=\mathrm{NF}_{\text {max }} \cdot \frac{Q_{\mathrm{Fe}}^{\mathrm{NF}}}{K_{\mathrm{Fe}}^{\mathrm{NF}}+Q_{\mathrm{Fe}}^{\mathrm{NF}}} \\
\mathrm{NF}^{\mathrm{Fe}}=\mathrm{NF}^{\mathrm{bsl}} \cdot\left(1-\left(1-10^{\mathrm{pH}-\mathrm{pH}_{\mathrm{bsl}}}\right) \cdot \frac{Q_{\mathrm{Fe}, \text { ref }}^{\mathrm{NF}}}{Q_{\mathrm{Fe}}^{\mathrm{NF}}}\right)
\end{gathered}
$$

Therefore, the modeled $\mathrm{N}_{2}$ fixation rate is the smaller of $\mathrm{NF}^{\mathrm{E}}$ and $\mathrm{NFFe}$. The $\mathrm{N}$-based growth rate $g_{\mathrm{N}}$ can be calculated by multiplying the $\mathrm{N}_{2}$ fixation rate with a molar C:N of 5.6, an average value obtained from our culture experiments. Then the modeled Trichodesmium growth rate, $g$, is the smaller of $g_{\mathrm{C}}$ and $g_{\mathrm{N}}$.

MATLAB optimization function fminsearch ${ }^{48}$ is used to solve Eq. (1) by optimizing the two unknown parameters $f_{\mathrm{Fe}}^{\mathrm{PS}}$ and $f_{\mathrm{E}}^{\mathrm{CF}}$ to obtain maximal $g$.

Cellular model simulation. To compare with the observations, the model first runs at the same $\mathrm{pH}$ and $p \mathrm{CO}_{2}$ levels as the ambient and acidified conditions of the culture experiments. The minimum intracellular Fe level of the simulation is 20 $\mu \mathrm{mol} \mathrm{Fe} \mathrm{(mol} \mathrm{C)})^{-1}$, as from our culture experiments the diazotroph cannot survive below this level. The model is then simulated for intracellular Fe level of 20-300 $\mu \mathrm{mol}(\mathrm{mol} \mathrm{C})^{-1}$ and environmental $\mathrm{pH}$ of 7.75-8.20, with $p \mathrm{CO}_{2}$ determined from varying $\mathrm{pH}$ and a constant alkalinity of $2200 \mu \mathrm{mol} \mathrm{kg} \mathrm{k}^{-1}$ under salinity of $35 \mathrm{PSU}$ and temperature of $35^{\circ} \mathrm{C}$ using the CO2SYS program (http://cdiac.ornl.gov/ftp/ co2sys/ $)^{49}$

Model experiments of individual OA effect. In each experiment, the model only enabled one OA effect: the reduced CCM energy consumption, the anti-stress energy consumption under lower $\mathrm{pH}$ or the reduced nitrogenase efficiency. Each experiment run over a $Q_{\mathrm{Fe}}$ range of $\left.20-300 \mu \mathrm{mol} \mathrm{Fe} \mathrm{(mol} \mathrm{C}\right)^{-1}$ at two $\mathrm{pH}$ levels of 8.02 and 7.82, with the $p \mathrm{CO}_{2}$ determined in same way as used above. The relative change of the modeled growth rate at the two $\mathrm{pH}$ levels was calculated for each experiment. The relative changes of $\mathrm{Fe}$ in nitrogenase and photosystems and energy production rate were also calculated for the anti-stress energy consumption only and the reduced nitrogenase efficiency only experiments.

A light-limiting experiment was set up in which the maximum energy production rate is $560 \mathrm{~kJ}(\mathrm{~mol} \mathrm{C})^{-1} \mathrm{~d}^{-1}$, a rate that corresponds to the ambient high-Fe treatment of the culture experiment, and the anti-stress energy consumption was enabled as the only OA effect.

Projection of Trichodesmium's potential to fix $\mathbf{N}_{2}$. Our study projects Trichodesmium's potential to fix $\mathrm{N}_{2}$ (per Trichodesmium $\mathrm{C}$ biomass per unit time) solely determined by $\mathrm{Fe}$ and $\mathrm{pH} / \mathrm{pCO}_{2}$. We first collected in situ Trichodesmium Fe quota $\left(Q_{\mathrm{Fe}}\right)$ measurements from literature $24,50-55$, and binned them according to their sampling location $\left(1^{\circ} \times 1^{\circ}\right)$ and time (month) (Supplementary Figure 5). We obtained the inorganic $\mathrm{Fe}$ concentration $\left(\mathrm{Fe}^{\prime}\right)$ in surface ocean in 1990s from model CESM-BGC 56 , which appears one of the best models in fitting to the measured dissolved $\mathrm{Fe}^{57}$. The monthly climatology of $\mathrm{Fe}^{\prime}$ in 1990s was calculated. $\mathrm{Q}_{\mathrm{Fe}}$ and the modeled $\mathrm{Fe}^{\prime}$ at same location/time were compared. Similar to the observation in laboratory experiments ${ }^{4}$, a linear regression was calculated for $\log \left(Q_{\mathrm{Fe}}\right)$ and $\log \left(\mathrm{Fe}^{\prime}\right)$, in which a data source ${ }^{54}$ was excluded because it used a different method from and obtained much lower $Q_{\mathrm{Fe}}$ than other studies, and therefore may not be directly comparable to other data sources. The obtained regression between $\log \left(Q_{\mathrm{Fe}}\right)$ and $\log \left(\mathrm{Fe}^{\prime}\right)$ was then used to estimate Trichodesmium $Q_{\mathrm{Fe}}$ from the CESM-BGC surface $\mathrm{Fe}^{\prime}$ in 1990 s between $35^{\circ} \mathrm{S}$ and $35^{\circ} \mathrm{N}$, a probable range that Trichodesmium may exist ${ }^{12,58}$.

We further obtained the CESM-BGC RCP 8.5 modeled surface $\mathrm{pH}$ and $p \mathrm{CO}_{2}$ in 1990s and 2090s (Supplementary Figure 6), which, together with the above estimated Trichodesmium $Q_{\mathrm{Fe}}$, were used as inputs of the cellular model to project the monthly Trichodesmium $\mathrm{N}_{2}$ fixation potential in these two periods. The monthly projections were averaged to annual estimates. We did not consider the change of $\mathrm{Fe}^{\prime}$, and therefore $Q_{\mathrm{Fe}}$, in these two periods, because large uncertainties exist in projecting the change of the $\mathrm{Fe}$ deposition to the future ocean ${ }^{59}$.

The source of the CESM-BGC data was the University Corporation for Atmospheric Research (UCAR) at http://www.earthsystemgrid.org. () 2002 University Corporation for Atmospheric Research. All Rights Reserved.

\section{Data availability}

All measurement data generated or analyzed during this study are included in this published article and its supplementary information files. Data generated by models during this study are available from the correspondence authors on request.

\section{Code availability}

The computer code of the model used in this study are available from the correspondence authors on reasonable request.

Received: 17 June 2018 Accepted: 19 March 2019

Published online: 03 April 2019

\section{References}

1. Gruber, N. The marine nitrogen cycle: overview and challenges, in Nitrogen in the marine environment 2 nd edn (eds. D. G. Capone, D. A. Bronk, M. R. Mulholland, \& E. J. Carpenter) 1-50 (Elsevier, Burlington, 2008).

2. Doney, S. C., Fabry, V. J., Feely, R. A. \& Kleypas, J. A. Ocean acidification: the other $\mathrm{CO}_{2}$ problem. Ann. Rev. Mar. Sci. 1, 169-192 (2009).

3. Dutkiewicz, S. et al. Impact of ocean acidification on the structure of future phytoplankton communities. Nat. Clim. Change 5, 1002-1006 (2015).

4. Shi, D., Kranz, S. A., Kim, J.-M. \& Morel, F. M. M. Ocean acidification slows nitrogen fixation and growth in the dominant diazotroph Trichodesmium under low-iron conditions. Proc. Natl Acad. Sci. 109, E3094-E3100 (2012).

5. Böttjer, D., Karl, D. M., Letelier, R. M., Viviani, D. A. \& Church, M. J. Experimental assessment of diazotroph responses to elevated seawater $p \mathrm{CO}_{2}$ in the North Pacific Subtropical Gyre. Glob. Biogeochem. Cycles 28, 601-616 (2014)

6. Gradoville, M. R., White, A. E., Böttjer, D., Church, M. J. \& Letelier, R. M. Diversity trumps acidification: Lack of evidence for carbon dioxide enhancement of Trichodesmium community nitrogen or carbon fixation at Station ALOHA. Limnol. Oceanogr. 59, 645-659 (2014).

7. Hong, H. et al. The complex effects of ocean acidification on the prominent $\mathrm{N}_{2}$-fixing cyanobacterium Trichodesmium. Science 356, 527-531 (2017).

8. Levitan, O. et al. Elevated $\mathrm{CO}_{2}$ enhances nitrogen fixation and growth in the marine cyanobacterium Trichodesmium. Glob. Chang. Biol 13, 531-538 (2007).

9. Kranz, S. A., Dieter, S., Richter, K.-U. \& Rost, B. Carbon acquisition by Trichodesmium: The effect of $p \mathrm{CO}_{2}$ and diurnal changes. Limnol. Oceanogr. 54, 548-559 (2009).

10. Barcelos e Ramos, J., Biswas, H., Schulz, K. G., LaRoche, J. \& Riebesell, U. Effect of rising atmospheric carbon dioxide on the marine nitrogen fixer Trichodesmium. Glob. Biogeochem. Cycles 21, GB2028 (2007).

11. Hutchins, D. A. et al. $\mathrm{CO}_{2}$ control of Trichodesmium $\mathrm{N}_{2}$ fixation, photosynthesis, growth rates, and elemental ratios: Implications for past, present, and future ocean biogeochemistry. Limnol. Oceanogr. 52, 1293-1304 (2007).

12. Sohm, J. A., Webb, E. A. \& Capone, D. G. Emerging patterns of marine nitrogen fixation. Nat. Rev. Microbiol. 9, 499-508 (2011).

13. Moore, C. M. et al. Large-scale distribution of Atlantic nitrogen fixation controlled by iron availability. Nat. Geosci. 2, 867-871 (2009). 
14. Chappell, P. D., Moffett, J. W., Hynes, A. M. \& Webb, E. A. Molecular evidence of iron limitation and availability in the global diazotroph Trichodesmium. ISME J. 6, 1728-1739 (2012).

15. Kustka, A. B. et al. Iron requirements for dinitrogen- and ammoniumsupported growth in cultures of Trichodesmium (IMS 101): Comparsion with nitrogen fixation rates and iron:carbon ratios of field populations. Limnol. Oceanogr. 48, 1869-1884 (2003).

16. Brown, C. M., MacKinnon, J. D., Cockshutt, A. M., Villareal, T. A. \& Campbell, D. A. Flux capacities and acclimation costs in Trichodesmium from the Gulf of Mexico. Mar. Biol. 154, 413-422 (2008).

17. Howard, J. B. \& Rees, D. C. Structural basis of biological nitrogen fixation. Chem. Rev. 96, 2965-2982 (1996).

18. Raven, J. A. The iron and molybdenum use efficiencies of plant growth with different energy, carbon and nitrogen sources. New Phytol. 109, 279-287 (1988).

19. Shi, T., Sun, Y. \& Falkowski, P. G. Effects of iron limitation on the expression of metabolic genes in the marine cyanobacterium Trichodesmium erythraeum IMS101. Environ. Microbiol. 9, 2945-2956 (2007).

20. Küpper, H. et al. Iron limitation in the marine cyanobacterium Trichodesmium reveals new insights into regulation of photosynthesis and nitrogen fixation. New Phytol. 179, 784-798 (2008).

21. Berman-Frank, I. et al. Segregation of nitrogen fixation and oxygenic photosynthesis in the marine cyanobacterium Trichodesmium. Science 294, 1534-1537 (2001).

22. Bergman, B., Sandh, G., Lin, S., Larsson, J. \& Carpenter, E. J. Trichodesmiuma widespread marine cyanobacterium with unusual nitrogen fixation properties. FEMS Microbiol. Rev. 37, 286-302 (2013).

23. Castruita, M. et al. Overexpression and characterization of an iron storage and DNA-binding Dps protein from Trichodesmium erythraeum. Appl. Environ. Microbiol. 72, 2918-2924 (2006).

24. Berman-Frank, I., Cullen, J. T., Shaked, Y., Sherrell, R. M. \& Falkowski, P. G. Iron availability, cellular iron quotas, and nitrogen fixation in Trichodesmium. Limnol. Oceanogr. 46, 1249-1260 (2001).

25. Harrison, P. M. \& Arosio, P. The ferritins: molecular properties, iron storage function and cellular regulation. Biochim. Biophys. Acta 1275, 161-203 (1996).

26. Kustka, A., Sañudo-Wilhelmy, S., Carpenter, E. J., Capone, D. G. \& Raven, J. A. A revised estimate of the iron use efficiency of nitrogen fixation, with special reference to the marine cyanobacterium Trichodesmium spp. (Cyanophyta). J. Phycol. 39, 12-25 (2003).

27. Pham, D. N. \& Burgess, B. K. Nitrogenase reactivity: effects of $\mathrm{pH}$ on substrate reduction and carbon monoxide inhibition. Biochemistry 32, 13725-13731 (1993).

28. Price, G. D., Maeda, S.-i, Omata, T. \& Badger, M. R. Modes of active inorganic carbon uptake in the cyanobacterium, Synechococcus sp. PCC7942. Funct. Plant Biol. 29, 131-149 (2002).

29. Price, G. D., Badger, M. R., Woodger, F. J. \& Long, B. M. Advances in understanding the cyanobacterial $\mathrm{CO}_{2}$-concentrating-mechanism (CCM): functional components, $\mathrm{Ci}$ transporters, diversity, genetic regulation and prospects for engineering into plants. J. Exp. Bot. 59, 1441-1461 (2008).

30. Raven, J. A., Beardall, J. \& Giordano, M. Energy costs of carbon dioxide concentrating mechanisms in aquatic organisms. Photosynth. Res. 121, 111-124 (2014).

31. Subramanian, S., Barry, A. N., Pieris, S. \& Sayre, R. T. Comparative energetics and kinetics of autotrophic lipid and starch metabolism in chlorophytic microalgae: implications for biomass and biofuel production. Biotechnol. Biofuels. 6, 150 (2013).

32. Eichner, M., Kranz, S. A. \& Rost, B. Combined effects of different $\mathrm{CO}_{2}$ levels and $\mathrm{N}$ sources on the diazotrophic cyanobacterium Trichodesmium. Physiol. Plant. 152, 316-330 (2014).

33. Eichner, M., Thoms, S., Kranz, S. A. \& Rost, B. Cellular inorganic carbon fluxes in Trichodesmium: a combined approach using measurements and modelling. J. Exp. Bot. 66, 749-759 (2015).

34. Reinfelder, J. R. Carbon concentrating mechanisms in eukaryotic marine phytoplankton. Ann. Rev. Mar. Sci. 3, 291-315 (2011).

35. Badger, M. R. et al. The diversity and coevolution of Rubisco, plastids, pyrenoids, and chloroplast-based $\mathrm{CO}_{2}$-concentrating mechanisms in algae. Can. J. Bot. 76, 1052-1071 (1998).

36. Hopkinson, B. M., Young, J. N., Tansik, A. L. \& Binder, B. J. The minimal $\mathrm{CO}_{2}$-concentrating mechanism of Prochlorococcus spp. MED4 is effective and efficient. Plant Physiol. 166, 2205-2217 (2014).

37. Capone, D. G. Determination of nitrogenase activity in aquatic samples using the acetylene reduction procedure, in Handbook of Methods in Aquatic Microbial Ecology, (eds. P. F. Kemp, Jonathan J. Cole, Barry F. Sherr, \& Evelyn B. Sherr) 621-631 (Lewis Publishers, Boca Raton, 1993).

38. Postgate, J. R. The Fundamentals of Nitrogen Fixation. (Cambridge University Press, New York, 1998).
39. Hopkinson, B. M., Dupont, C. L., Allen, A. E. \& Morel, F. M. M. Efficiency of the $\mathrm{CO}_{2}$-concentrating mechanism of diatoms. Proc. Natl Acad. Sci USA 108, 3830-3837 (2011)

40. Levitan, O., Sudhaus, S., LaRoche, J. \& Berman-Frank, I. The influence of $\mathrm{pCO}_{2}$ and temperature on gene expression of carbon and nitrogen pathways in Trichodesmium IMS101. PLoS. ONE 5, e15104 (2010).

41. Short, S. M. \& Zehr, J. P. Quantitative analysis of nifH genes and transcripts from aquatic environments, in Methods Enzymol, Vol. 397, 380-394 (Academic Press, New York, 2005).

42. Hageman, R. V. \& Burris, R. H. Electron allocation to alternative substrates of Azotobacter nitrogenase is controlled by the electron flux through dinitrogenase. Biochim. Biophys. Acta 591, 63-75 (1980).

43. Tagliabue, A. et al. The integral role of iron in ocean biogeochemistry. Nature 543, 51-59 (2017)

44. Carpenter, E. J. \& Capone, D. G. Significance of Trichodesmium blooms in the marine nitrogen cycle, in Marine Pelagic Cyanobacteria: Trichodesmium and other Diazotrophs, (eds. E. J. Carpenter, D. G. Capone, \& J. G. Rueter) 211-217 (Kluwer Academic Publishers, Dordrecht, 1992).

45. Rodriguez, I. B. \& Ho, T.-Y. Influence of Co and B12 on the growth and nitrogen fixation of Trichodesmium. Front. Microbiol. 6, 623 (2015).

46. Boatman, T. G., Lawson, T. \& Geider, R. J. A key marine diazotroph in a changing ocean: the interacting effects of temperature, $\mathrm{CO}_{2}$ and light on the growth of Trichodesmium erythraeum IMS101. PLoS. ONE 12, e0168796 (2017).

47. Sunda, W. G., Price, N. M. \& Morel, F. M. M. Trace mental ion buffers and their use in culture studies, in Algal Culturing Techniques, (ed. Robert A. Andersen) 35-63 (Academic press, San Diego, 2005).

48. Lagarias, J. C., Reeds, J. A., Wright, M. H. \& Wright, P. E. Convergence properties of the Nelder-Mead simplex method in low dimensions. SIAM J. Optim. 9, 112-147 (1998).

49. Lewis, E. \& Wallace, D. W. R. Program developed for $\mathrm{CO}_{2}$ system calculations Report No. ORNL/CDIAC-105. (Carbon Dioxide Information Analysis Center, Oak Ridge National Laboratory, U.S. Department of Energy, Oak Ridge, 1998).

50. Jones, G., Burdon-Jones, C. \& Thomas, F. Influence of Trichodesmium red tides on trace metal cycling at a coastal station in the Great Barrier Reef lagoon. Oceanologica Acta 5, 319-326 (1982).

51. Orcutt, K. M. et al. A seasonal study of the significance of $\mathrm{N}_{2}$ fixation by Trichodesmium spp. at the Bermuda Atlantic Time-series Study (BATS) site. Deep-Sea. Res. II 48, 1583-1608 (2001).

52. Elardo, K. M. Changes in proteins associated with nitrogen fixation and iron nutrition in the marine cyanobacterium Trichodesmium. M.S. thesis, Portland State University, Portland, (1995).

53. Rueter, J. G., Hutchins, D. A., Smith, R. W. \& Unsworth, N. L. Iron nutrition of Trichodesmium. in Marine pelagic cyanobacteria: Trichodesmium and other diazotrophs (eds. E. J. Carpenter, D. G. Capone, \& J. G. Rueter) 289-306 (Kluwer Academic Publishers, Dordrecht, 1992).

54. Sañudo-Wilhelmy, S. A. et al. Phosphorus limitation of nitrogen fixation by Trichodesmium in the central Atlantic Ocean. Nature 411, 66-69 (2001).

55. Tuit, C., Waterbury, J. \& Ravizzaz, G. Diel variation of molybdenum and iron in marine diazotrophic cyanobacteria. Limnol. Oceanogr. 49, 978-990 (2004).

56. Moore, J. K., Lindsay, K., Doney, S. C., Long, M. C. \& Misumi, K. Marine ecosystem dynamics and biogeochemical cycling in the Community Earth System Model [CESM1(BGC)]: comparison of the 1990s with the 2090s under the RCP4.5 and RCP8.5 scenarios. J. Clim. 26, 9291-9312 (2013).

57. Tagliabue, A. et al. How well do global ocean biogeochemistry models simulate dissolved iron distributions? Glob. Biogeochem. Cycles 30, 149-174 (2016).

58. Luo, Y.-W. et al. Database of diazotrophs in global ocean: abundance, biomass and nitrogen fixation rates. Earth Syst. Sci. Data 4, 47-73 (2012).

59. Mahowald, N. M. et al. Atmospheric iron deposition: global distribution, variability, and human perturbations. Ann. Rev. Mar. Sci. 1, 245-278 (2009).

60. Raven, J. A., Kübler, J. E. \& Beardall, J. Put out the light, and then put out the light. J. Mar. Biol. Assoc. UK 80, 1-25 (2000).

61. Flores, E. \& Herrero, A. Assimilatory nitrogen metabolism and its regulation. in The Molecular Biology of Cyanobacteria (ed. D. A. Bryant) 487-517 (Kluwer Academic Publishers, Dordrecht, 1994).

62. Flores, E., Frías, J. E., Rubio, L. M. \& Herrero, A. Photosynthetic nitrate assimilation in cyanobacteria. Photosynth. Res. 83, 117-133 (2005).

\section{Acknowledgements}

This work was funded by the National Key R\&D Program of China (2016YFA0601404 and 2016YFA0601203), NSFC (41476093, 41721005, 41890802, 31861143022 and 41376116), and the MEL internal research fund (MELRI1502). 


\section{Author contributions}

Y-W.L., D.S., and H.H. originated concept for the study. D.S., H.H., R.S., and F.Z. designed and performed laboratory experiments. Y-W.L. and D.S. designed numerical model. Y-W.L. coded and performed numerical modeling. Y-W.L., D.S., S.A.K., and B.M.H. analyzed results, improved the numerical model, and wrote the manuscript.

\section{Additional information}

Supplementary Information accompanies this paper at https://doi.org/10.1038/s41467019-09554-7.

Competing interests: The authors declare no competing interests.

Reprints and permission information is available online at http://npg.nature.com/ reprintsandpermissions/

Journal peer review information: Nature Communications thanks Adam Kustka and the other anonymous reviewers for their contribution to the peer review of this work. Peer reviewer reports are available.
Publisher's note: Springer Nature remains neutral with regard to jurisdictional claims in published maps and institutional affiliations.

(c) (i) Open Access This article is licensed under a Creative Commons Attribution 4.0 International License, which permits use, sharing, adaptation, distribution and reproduction in any medium or format, as long as you give appropriate credit to the original author(s) and the source, provide a link to the Creative Commons license, and indicate if changes were made. The images or other third party material in this article are included in the article's Creative Commons license, unless indicated otherwise in a credit line to the material. If material is not included in the article's Creative Commons license and your intended use is not permitted by statutory regulation or exceeds the permitted use, you will need to obtain permission directly from the copyright holder. To view a copy of this license, visit http://creativecommons.org/ licenses/by/4.0/.

(c) The Author(s) 2019 